\title{
Quaternary glaciation history of northern Switzerland
}

\author{
Frank Preusser, Hans Rudolf Graf, Oskar Keller, Edgar Krayss, Christian Schlüchter
}

Abstract:

\begin{abstract}
A revised glaciation history of the northern foreland of the Swiss Alps is presented by summarising field evidence and chronological data for different key sites and regions. The oldest Quaternary sediments of Switzerland are multiphase gravels intercalated by till and overbank deposits ('Deckenschotter'). Important differences in the base level within the gravel deposits allows the distinguishing of two complex units ('Höhere Deckenschotter', 'Tiefere Deckenschotter'), separated by a period of substantial incision. Mammal remains place the older unit ('Höhere Deckenschotter') into zone MN 17 (2.6-1.8 Ma). Each of the complexes contains evidence for at least two, but probably up-to four, individual glaciations. In summary, up-to eight Early Pleistocene glaciations of the Swiss alpine foreland are proposed. The Early Pleistocene 'Deckenschotter' are separated from Middle Pleistocene deposition by a time of important erosion, likely related to tectonic movements and/or re-direction of the Alpine Rhine (Middle Pleistocene Reorganisation - MPR). The Middle-Late Pleistocene comprises four or five glaciations, named Möhlin, Habsburg, Hagenholz (uncertain, inadequately documented), Beringen, and Birrfeld after their key regions. The Möhlin Glaciation represents the most extensive glaciation of the Swiss alpine foreland while the Beringen Glaciation had a slightly lesser extent. The last glacial cycle (Birrfeld Glaciation) probably comprises three independent glacial advances dated to ca. $105 \mathrm{ka}, 65 \mathrm{ka}$, and $25 \mathrm{ka}$. For the last glacial advance, a detailed radiocarbon chronology for ice build-up and meltdown is presented.
\end{abstract}

\section{[Quartäre Vergletscherungsgeschichte der nördlichen Schweiz]}

Kurzfassung: $\quad$ Eine revidierte Vergletscherungsgeschichte des nördlichen Vorlandes der Schweizer Alpen wird vorgestellt, basierend auf Feldbefunden und chronologischen Daten von verschiedenen Schlüssellokalitäten und Regionen. Die ältesten quartären Sedimente der Schweiz sind mehrphasige Kiese, in die Till und Hochflutsedimente eingeschaltet sind ('Deckenschotter'). Bedeutende Unterschiede im Basisniveau der Schotterablagerungen erlauben die Unterscheidung zweier komplex augebauter Einheiten ('Höhere Deckenschotter', 'Tiefere Deckenschotter'), die durch eine Phase bedeutender Einschneidung getrennt sind. Säugetierreste stellen die ältere Einheit ('Höhere Deckenschotter') in die Zone MN 17 (2.6-1.8 Ma). Jeder der Komplexe enthält Belege für zumindest zwei, möglicherweise sogar bis zu vier eigenständige Eiszeiten, woraus sich in Summe bis zu acht frühpleistozäne Vergletscherungen des Schweizer Alpenvorlands ergeben. Die frühpleistozänen Deckenschotter sind von mittelpleistozänen Ablagerungen durch eine Zeit bedeutender Erosion getrennt, die wahrscheinlich durch tektonische Bewegungen und/oder eine Umleitung des Alpenrheins verursacht wurde (Mittelpleistozäne Reorganisation - MPR). Das Mittel-/Spätpleistozän beinhaltet vier oder fünf Eiszeiten, die nach ihren Schlüsselregionen als Möhlin-, Habsburg-, Hagenholz- (unsicher, unzureichend belegt), Beringen- und Birrfeld-Eiszeit benannt sind. Die Möhlin-Eiszeit repräsentiert die grösste Vergletscherung des Schweizer Alpenvorlandes, während die BeringenEiszeit von nur wenig geringerer Ausdehnung war. Der letzte Glazialzyklus (Birrfeld-Eiszeit) umfasst wahrscheinlich drei eigenständige Gletschervorstösse, die auf ca. 105 ka, 65 ka und 25 ka datiert wurden. Für den letzten Eisvorstoss wird eine detaillierte Radiokohlenstoffchronologie für den Eisaufbau und das Abschmelzen präsentiert.

Keywords: $\quad$ Alps, glaciation, stratigraphy, chronology, glacial deposits

Addresses of authors: F. Preusser *, Institut für Geologie, Universität Bern, Baltzerstrasse 1+3, 3012 Bern, Switzerland. Present address: Department of Physical Geography and Quaternary Geology, Stockholm University, 10691 Stockholm, Sweden. E-Mail: frank.preusser@ natgeo.su.se; H. R. Graf, Dorfstrasse 40, 8014 Gächlingen, Switzerland; O. Keller, Brühlstrasse 90, 9320 Arbon, Switzerland; E. Krayss, Myrtenstrasse 9, 9010 St. Gallen, Switzerland; C. Schlüchter, Institut für Geologie, Universität Bern, Baltzerstrasse 1+3, 3012 Bern, Switzerland. *corresponding author

\section{Introduction}

The Swiss Alps are the area where the theory of past glaciations of the lowlands was originally developed by Perraudin and published by Venetz (1833). The glaciation theory was later further elaborated and promoted by, for example, AgAssiz (1837) and DE CHARPENTIER (1841), but it was again VENETZ (1861) who brought up the idea that glaciers may have reached the lowlands several times in the past. The tetra-partition of the ice age was later internationally established by PENCK \& BRÜCKNER (1901/09) who observed four different levels of former out-wash plains in the Iller Valley, Bavaria, each of which is expected to represent a discrete glaciation. Proof of the glacial character of the gravel deposits is given by the connection of the younger three units to glacial series, i.e. terminal moraine ridges and glacial basins. The four glaciations deduced from this evidence have been named after small rivers in Bavaria (from old to young: Günz, Mindel, Riss, and Würm), and this stratigraphical scheme has been adopted at least for some time in many parts of the world. It is important to note that the original PENCK \& BRÜCKNER (1901/09) scheme was later modified and extended by three further glacial complexes (Donau: EberL 1930; Biber: SCHAEFER 1957; Haslach: SCHREINER \& Ebel 1981). However, until now these stratigraphical units have not been recognised outside southern Germany.

In Switzerland, the four-fold PENCK \& BRÜCKNER (1901/09) concept was widely accepted for a long time. It has been assumed that the four glaciations found in Bavaria 


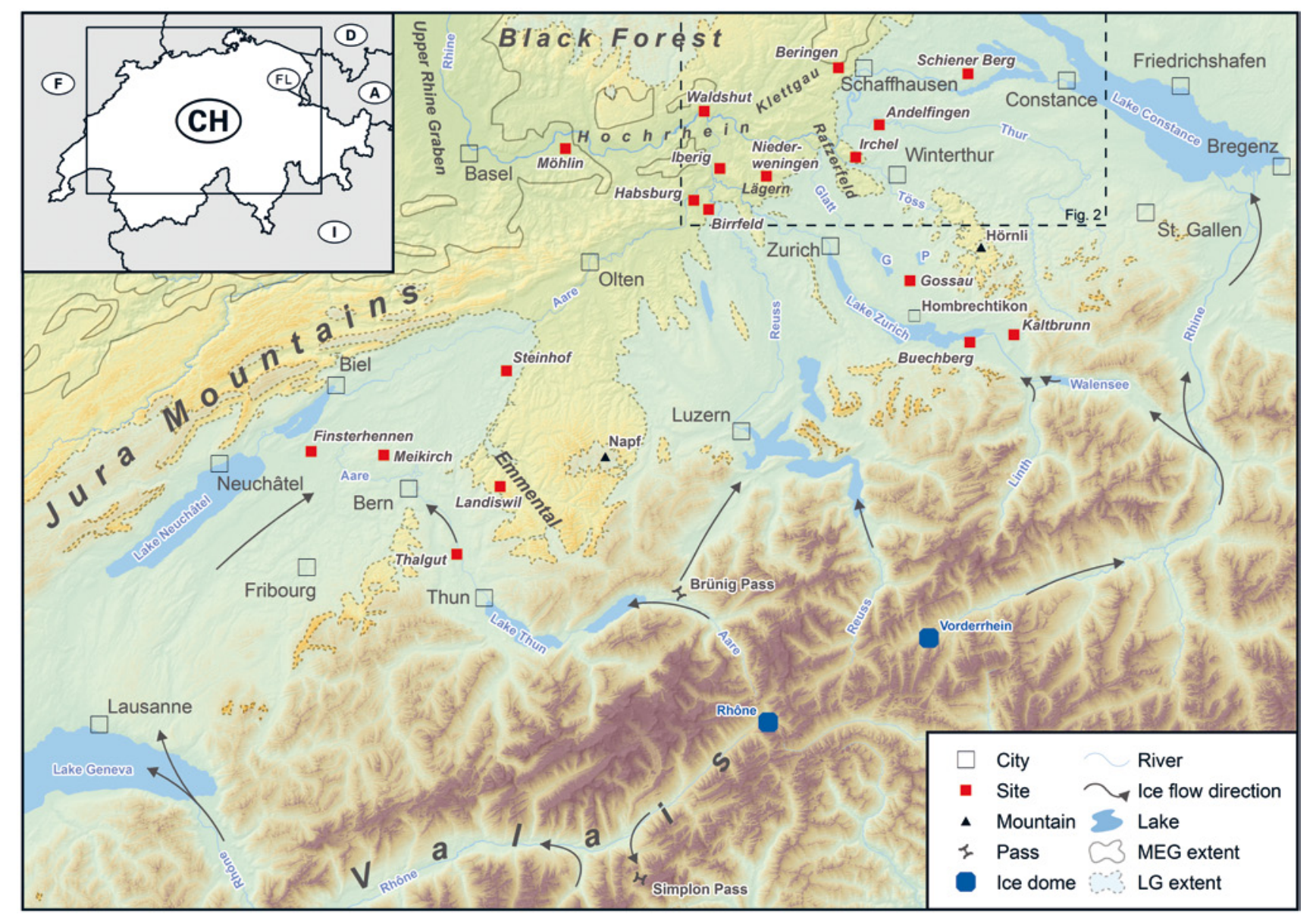

Fig. 1: Overview map of the study in northern Switzerland, with the location of ice domes and ice flow directions (after FLORINETH 1998; FLORINETH \& SCHLÜCHTER 1998; KELLY et al. 2004), and the location of key regions and sites mentioned in the text ( $G=$ Greifensee; P = Pfäffikersse; LG = Maximum extent of the Last Glaciation; $M E G=$ Extent of the Most Extensive Glaciation).

Abb. 1: Übersichtskarte des Untersuchungsgebietes in der Nordschweiz mit der Lage von Eisdomen und Eisflussrichtungen (nach FLORINETH 1998; FLORINETH \& SCHLÜCHTER 1998; KELLY et al. 2004), sowie der Lage von Schlüsselregionen und Ortlichkeiten, die im Text vermerkt sind (G = Greifensee; P = Pfäffikersse; $L G$ = Maximale Ausdehnung der letzten Vergletscherung; MEG = Ausdehnung der Grössten Vergletscherung).

are represented by the morphological features of Low Terrace (Würm), High Terrace (Riss), 'Tiefere Deckenschotter' (Mindel), and 'Höhere Deckenschotter' (Günz). An alternative view of the glaciation history of the Swiss lowlands was introduced by SCHLÜCHTER (1988), who combined geomorphological observations with detailed logging of sections and establishing lithostratigraphical models. According to this scheme, glaciers reached the lowlands of Switzerland at least 15 times during the Quaternary, which is much more often than previously assumed.

This contribution aims at providing a comprehensive overview of the present knowledge of the Quaternary history of the northern foreland of the Swiss Alps, based on evidence for different key areas and sites (locations are given in Fig. 1). The oldest Quaternary deposits are the so-called 'Deckenschotter' of northern Switzerland, which probably comprise the largest part of the Early Pleistocene development. The new terminology introduced by GRAF (2009a) comprises five Middle to Late Pleistocene glaciations (from old to young): Möhlin, Habsburg, Hagenholz, Beringen, and Birrfeld. Evidences for this new stratigraphical scheme will be summarised and are mainly based on previous studies by GRAF (2009a) and Keller \& KraYsS (2010). As correlations with the stratigraphic scheme of
PENCK \& BRÜCKNER (1901/09) are not yet reliably established, this article will desist from using nomenclature established for Bavaria. Detailed reviews of the Late Quaternary environmental history of the region and glacial dynamics are not given here, as these have already been provided by Preusser (2004) and Ivy-Ochs et al. (2008, 2009).

\section{Geological, topographic and palaeo-glaciological setting}

The area considered here comprises the northern foreland of the Swiss Alps from the eastern edge of Lake Neuchâtel in the west to the western banks of Lake Constance in the east (Fig. 1). The Alps that form the southern border of the study area consist mainly of limestone and other sediments in their outer parts, and a variety of different magmatic and metamorphic rocks in their inner parts. The petrography of pebbles and boulders found in glacial deposits in the foreland has been used to reconstruct past ice flow patterns. To the north, the region of interest is bounded by the chain of the Jura Mountains, with peaks reaching altitudes of up to $1700 \mathrm{~m}$ a.s.l. and consisting mainly of limestone. The Jura mountain range has acted as a barrier with a major impact on ice flow in the western part of the region. To the east, 
the Jura mountain range lowers and Jurassic limestone is finally covered by Molasse sediments. The latter is debris eroded from the emerging Alps during the Tertiary and consists mainly of modestly cemented sandy to silty rocks with some conglomerates. In general, the Molasse area is made up of rolling hills, but in many areas glacial and fluvial erosion have formed pronounced relief and major valley drainage networks. The central part of the study area is made up of the midlands of Emmental and the Napf Mountains, the latter reaching a maximum height of $1408 \mathrm{~m}$ a.s.l. This area also acted as a barrier during past glaciations and was, apart from local glaciations in the highest parts of the Napf Mountains, not covered by ice during the Last Glaciation (SCHLÜCHTER 1987a; BinI et al. 2009; Fig. 1). Further to the east, the Hörnli Mountains similarly acted as a barrier dividing the Linth-Rhine Glacier and Lake ConstanceRhine Glacier during past glaciations (Keller \& KRAYsS 2005a; Fig. 1).

The entire northern foreland of the Swiss Alps, including the Lake Constance basin, is currently draining through the Hochrhein and the Upper Rhine Graben towards the North Sea (Fig. 1). In contrast, the foreland of the Bavarian and Austrian Alps drains through the River Danube towards the east, into the Black Sea. The reason for the much more pronounced relief in the Swiss Alpine foreland, compared to its continuation in the east, is probably due to the fact that the base level of the drainage is relatively low, with the subsiding Upper Rhine Graben, bounded to the east by the (still up-lifting?) massif of the Black Forest.

Quaternary glaciations of the foreland of the Swiss Alps were characterised by networks of transection glaciers that flow from the accumulation areas in the high mountains following major pre-existing valleys (Fig. 1). FlORINETH (1998), Florineth \& Schlüchter (1998), and Kelly et al. (2004) demonstrated for the Last Glaciation that several centres of ice accumulation existed to the south of the main alpine chain. This implies that moisture was transported from the south rather than the north, as is currently the case, indicating a significantly different atmospheric circulation pattern over central Europe during glacial times compared to the present (FLORINETH \& SCHLÜCHTER 2000). For the western part of our study area, the ice dome in the southern Valais was of major importance as it fed glaciers that flowed down-valley to Lake Geneva. There, part of the ice turned NE towards the Aare Valley, whereas the rest continued towards the SW following the Rhône Valley. In most previous studies, this ice mass was referred to as the Rhône Glacier. Kelly et al. (2004), however, have shown that Rhône Glacier sensu stricto (i.e. the present glacier located in the uppermost part of Valais) was blocked by ice from the southern Valais and was forced over Simplon Pass towards the south (Fig. 1).

In the area of the city of Bern, a confluence situation of the Valais Glacier and Aare Glacier, the latter originating from the Bernese Oberland, existed during the Last Glaciation and possibly also during older glaciations. Further up-valley, part of Aare Glacier flowed over Brünig Pass to join the Reuss Glacier in Central Switzerland (Fig. 1). To the east, the Linth Glacier and the (western) Walensee branch of the Rhine Glacier joined and continued further to the north. The main (eastern) branch of the Rhine Glacier formed a large piedmont ice lobe at the eastern edge of the study area, covering the area of the present Lake Constance.

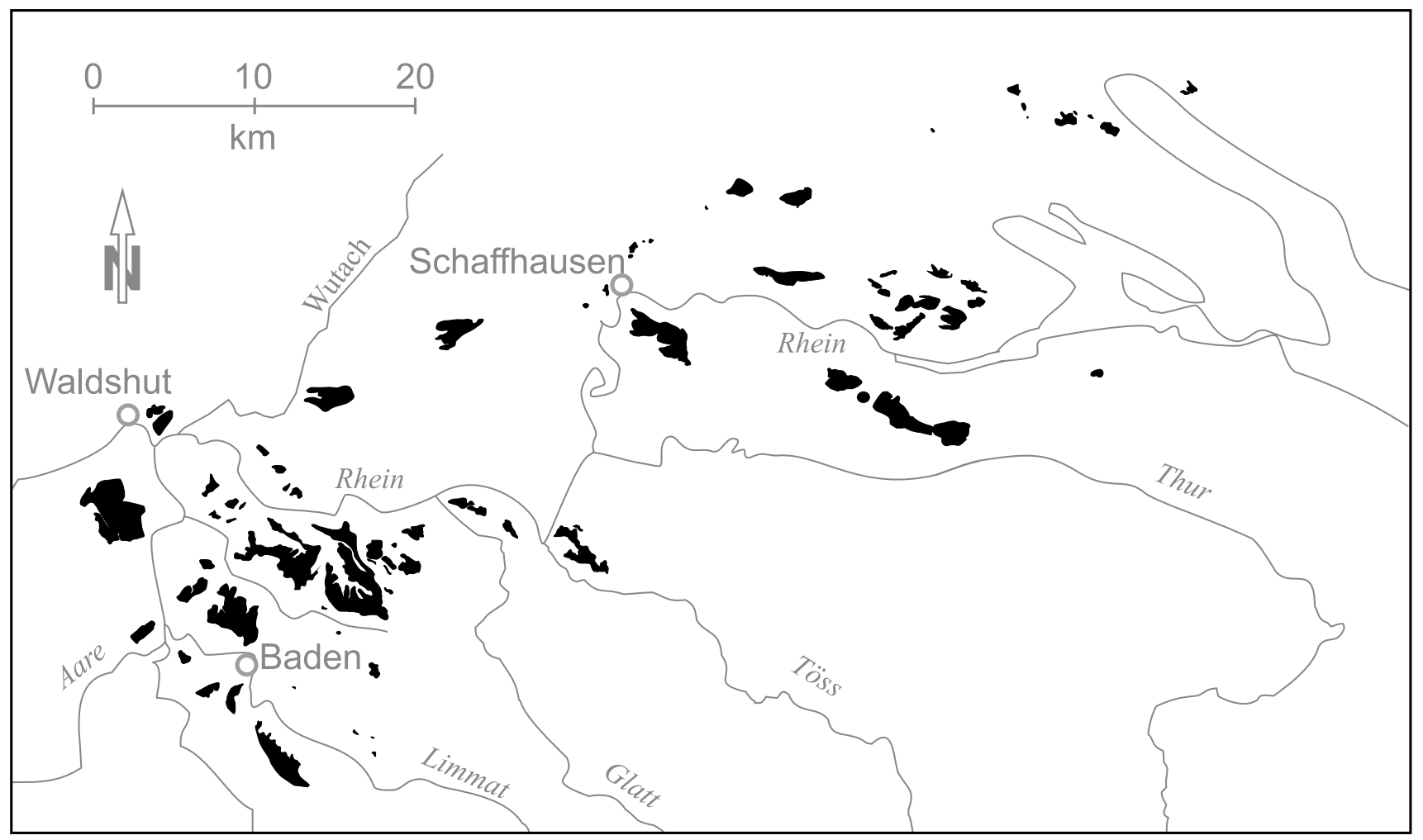

Fig. 2: Distribution of 'Deckenschotter' in northern Switzerland (modified after GRAF 1993, 2009b).

Abb. 2: Verteilung der Deckenschotter in der Nordschweiz (modifiziert nach GRAF 1993, 2009b). 


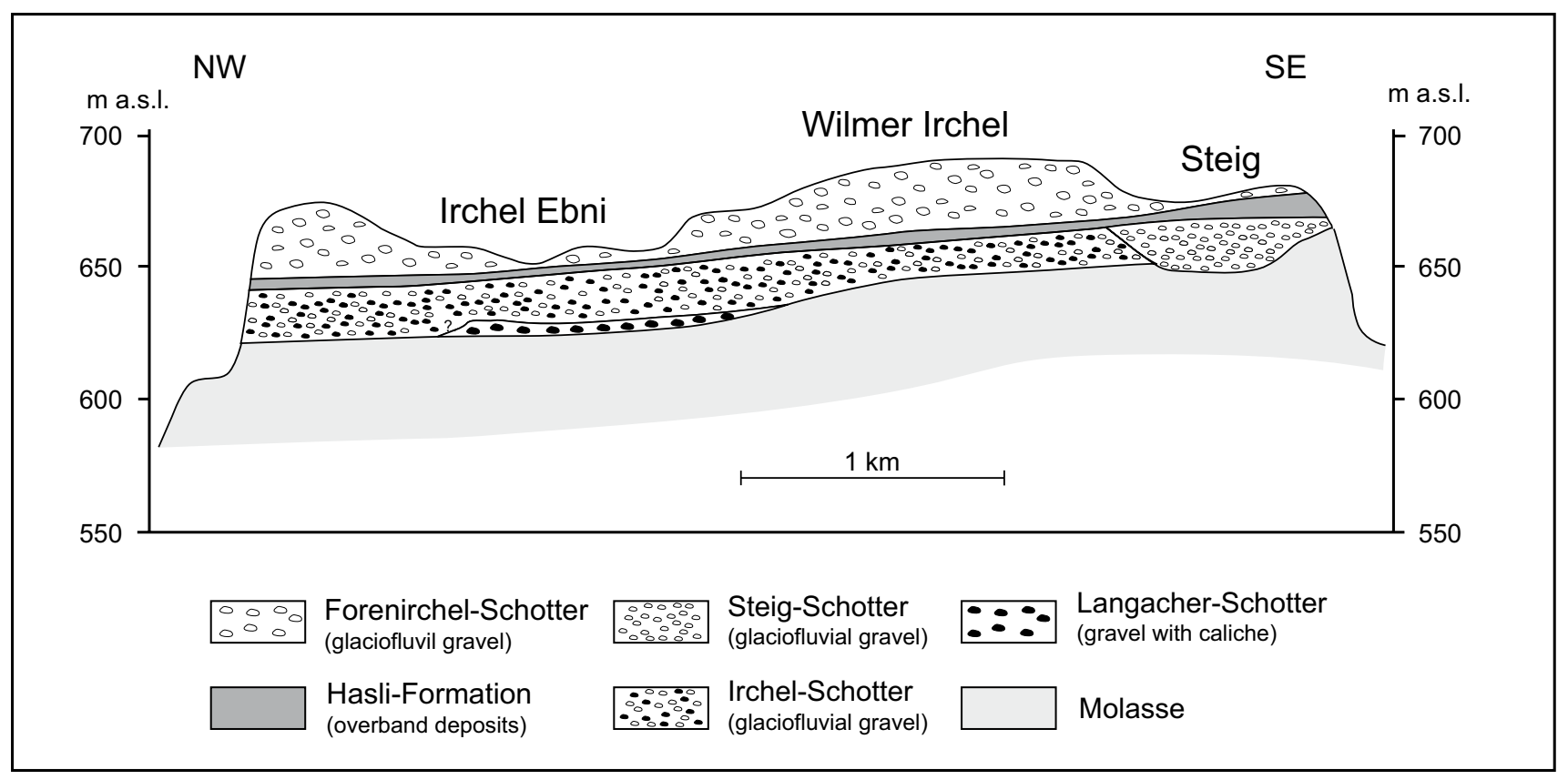

Fig. 3: Geological situation at Irchel ('Höhere Deckenschotter'; modified after GRAF 1993).

Abb. 3: Geologische Verhältnisse am Irchel (Höhere Deckenschotter; modifiziert nach GRAF 1993).

\section{Key sites and key regions}

\subsection{Early Pleistocene ['Deckenschotter glaciations']}

The oldest Pleistocene deposits of northern Switzerland, usually referred to as 'Deckenschotter', mainly consist of (glaciofluvial) gravel, with some intercalated glacial sediments (till) and overbank deposits. The present distribution of these deposits is between the easternmost part of the Jura Mountains ('Lägern'), the River Aare, the River Rhine, and Lake Constance (GRAF 1993). Lesser remnants of these strata are found to the east of Lake Constance (GrAF 2009b) as well as in some parts of northern Central Switzerland (Fig. 2). The remains of 'Deckenschotter' are typically found forming the top of table mountains.

The term 'Deckenschotter' was originally introduced by PENCK \& BRÜCKNER (1901/09) for deposits from Bavaria, and refers to past gravel accumulation on a broad-spread plain at the front of Alpine lowland glaciation. The 'Deckenschotter' of northern Switzerland, however, do not represent sheet-like gravel plain deposition on top of Molasse bedrock, but are the fills of several broad channels that are representing the past major drainage network of the northern Swiss Midlands (Graf 1993). 'Deckenschotter' deposits are found at two distinct topographic levels, and are therefore subdivided into a higher ('Höhere Deckenschotter') and a lower ('Tiefere Deckenschotter') unit. Both units represent depositional complexes. The channels of the lower (younger) unit have the same major drainage direction as the higher (older) unit, but are more deeply incised into Jurassic limestone and Molasse bedrock.

\subsubsection{Irchel}

The Quaternary deposits at Irchel, a tabular hill in northernmost Switzerland (Fig. 1), are a typical example of
'Höhere Deckenschotter' (GRAF 1993). The hill reaches for about $5 \mathrm{~km}$ from SE to NW, and Pleistocene deposits are found on top of Molasse bedrock, at an elevation between $620 \mathrm{~m}$ and $650 \mathrm{~m}$ a.s.l., thus about $300 \mathrm{~m}$ above the present drainage level.

The Quaternary deposits are subdivided into five units, four of which represent glaciofluvial outwash-gravel (Fig. 3). Petrographical analyses indicate an origin of the sediment from the Walensee-Rhine-System. The oldest unit ('Langacher-Schotter') contains a caliche-type palaeosol in its upper part that is characteristic for Mediterranean to dry-warm climatic conditions. The glaciofluvial gravel on top ('Irchel-Schotter') is cut by a channel-like structure in the SE. This channel is filled by younger glaciofluvial gravel ('Steig-Schotter') showing a prominent difference in petrography compared to the two older units. This implies that erosion was not a local phenomenon but rather indicates reorganisation of the entire drainage network. All over Irchel, the two previous units ('Irchel-Schotter', 'Steig-Schotter') are covered by overbank and channel fill deposits of a meandering river system, with a thickness between $2 \mathrm{~m}$ and $7 \mathrm{~m}$ ('Hasli-Formation'). These deposits document a phase of warm environmental conditions of a flood plain. The overbank deposits bear land snails and, of particular importance, vertebrate remains. The presence of Mimomys cf. pliocaenicus, M. reidi/pitymyoides, Borsodia, and Lagurodon, together with the absence of Microtus, is interpreted to indicate a correlation with Mammalian Neogen zone (MN) 17 (Gelasian), representing an age of 2.6-1.8 Ma (Bolliger et al. 1996). The next unit of glaciofluvial gravel ('Forenirchel-Schotter') found on top of the overbank deposits represents the youngest sediments at Irchel.

Although no glacial deposits have been documented at this particular site, such sediments (i.e. till) are found within the younger units of similar deposits of 'Höhere Deckenschotter' farther to the west (GRAF 1993). There it 


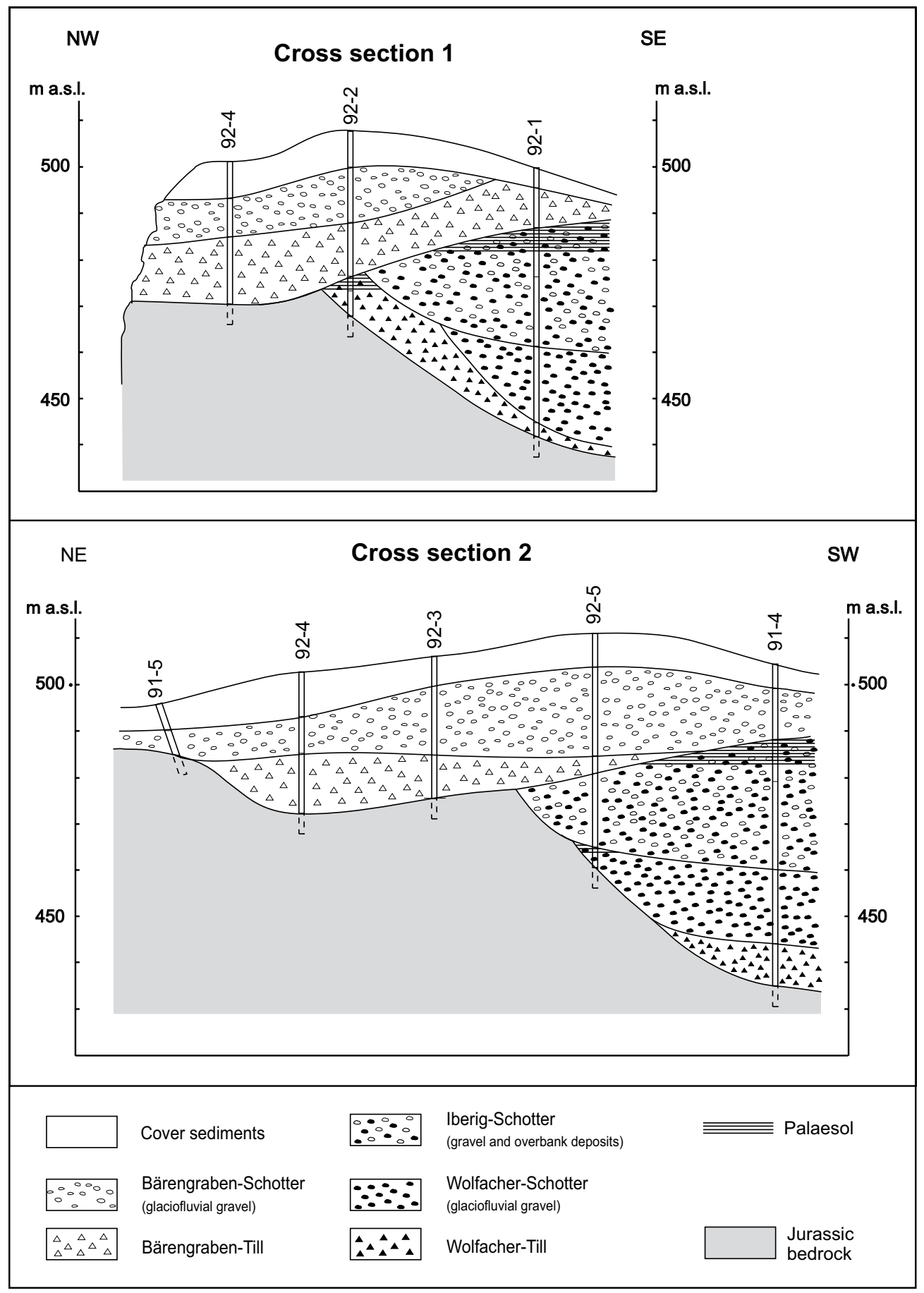

Fig. 4: Geological situation at Iberig ('Tiefere Deckenschotter'; modified after GRAF 1993).

Abb. 4: Geologische Verhältnisse am Iberig (Tiefere Deckenschotter; modifiziert nach GRAF 1993).

has been shown that at least two units clearly represent phases when alpine glaciers reached far into the eastern part of the Swiss alpine foreland during the Early Pleistocene (considering that the Neogene/Quaternary boundary is now at 2.6 Ma).

\subsubsection{Iberig}

The deposits at Iberig, a hill in the lower Aare Valley near Würenlingen, are situated at an elevation between 440-470 m a.s.l. (Fig. 1). Topographically this level is significantly lower than the one at Irchel, and therefore the deposits are considered to be part of 'Tiefere Deckenschotter'. Several drill holes revealed the presence of three glaciofluvial and two glacial units at this site (Fig. 4). From gravel petrography it is concluded that the lower till and the lower gravel unit ('Wolfacher-Schotter', 'Wolfacher-Till') are genetically related. The middle gravel unit ('Iberig-Schotter') reveals no petrographic relation to the glacigenic deposits, but the two upper units are again genetically related ('Bärengraben-Schotter', 'Bärengraben-Till'). Interestingly, the uppermost part of 'Iberig-Schotter' includes overbank deposits and palaeosols. This indicates, firstly, that glacial deposition was separated by sedimentation during warmer periods, and, secondly, that the fluvial drainage level remained similar during the glacial and non-glacial times of this period.

A similar threefold subdivision of 'Tiefere Deckenschotter' is found along the River Rhine (GRAF 1993), but a fourth gravel unit is found between Lake Constance and Klettgau as well as near Weiach ('Stein-Schotter') (GRAF 2009b). This 
channel system is cut into older deposits and indicates that 'Tiefere Deckenschotter' reflect at least four phases of glaciofluvial deposition, for two of which the presence of glaciers in the Swiss lowlands is clearly documented by the presence of till.

\subsection{Middle and Late Pleistocene ['basin glaciations']}

Middle and Late Pleistocene deposits outside the glacial limits are typically found as terrace bodies of glaciofluvial gravel along the drainage systems. Morphologically, a major differentiation has been made between the (older) High Terrace, mainly found at elevated positions up to several tens of metres above the valley floor, and the (younger) Low Terrace, usually only a few metres above the present river bed (cf. Kock et al. 2009). In the past, it has generally been assumed that the sediments of the two terrace systems have to be assigned exclusively to the Riss and Würm Glaciation. However, GrAf (2009a) has shown that both terrace units comprise sediments deposited during more than one glaciation and the most relevant evidences are summarised below. Interestingly, a complex deposition history of High Terrace aggradation has also been reported for Bavaria (Fiebig or Preusser 2003).

Within the limits of former glaciation extent, the presence of several deep basins and valleys below the sub-surface has been identified by drillings and geophysics, mainly between Lake Constance and the Napf Mountains, but also in the Aare Valley (cf. Preusser et al. 2010). The basal parts of these troughs even reach below sea-level (KeLLER 1994; Preusser et al. 2010), and the fills mainly consist of glacial sediments. These overdeepened structures are usually interpreted to result from glacial carving, and there is evidence that many of these troughs have been repeatedly occupied and excavated by glaciers during the Middle and Late Pleistocene (Preusser et al. 2010). The multiphase basin archives, accessible only by drilling, have provided major insights into the Quaternary history of the Swiss lowlands, and summaries of the most important archives are given in the following overview.

\subsubsection{Möhlinerfeld}

Between the villages Mumpf and Rheinfelden, the present River Rhine forms a bend towards the north and bypasses an elevated plateau, known as Möhlinerfeld (Fig. 1). The Pleistocene deposits found here are attributed to the complex of the High Terrace. The surface of bedrock is about $80 \mathrm{~m}$ below present land surface, showing a channel-like structure. This reveals that the River Rhine ones flowed straight across Möhlinerfeld. The present course of the river established in the final phase of the penultimate glaciation. From the north, the Wehra Valley, one of the most prominent river valleys draining the Black Forest high plateau to the south, joins the Rhine Valley.

Since PENCK \& BRÜCKNER (1901/09), Möhlinerfeld has been a reference for the so-called Most Extensive Glaciation of the Swiss Alpine foreland (cf. SCHLÜCHTER 1988). Originally two individual moraine ridges were distinguished from surface morphology. Recent evidence from the analyses of outcrops and coring revealed that this interpretation is incorrect. The sediments overlying the bedrock are subdivided into several units (Fig. 5), of which the oldest are found in the gravel pit Bünten in the southern part of the area. This unit consists of glacial deposits, a lodgement till with alpine material ('Bünten Till'), representing the advance of an alpine glacier towards this area (Möhlin advance). The till is covered by glaciofluvial gravel ('Bünten-Schotter'), showing an alpine spectrum, but the pebbles and boulders at its base consist of material originating from the Black Forest. In the pit, the uppermost part of the gravel shows intense weathering and this soil is interpreted to reflect interglacial conditions. The following unit is again gravel of alpine origin ('Wallbach-Schotter'), and this and the lower units are deformed by glaciotectonics. Towards the north, another gravel unit ("Möhlinerfeld-Schotter') is found on top of Wallbach gravel with an erosive contact. This gravel is dominated by alpine material but contains boulders and pebbles of Black Forest origin. The boulder horizon probably reflects the erosional remains of an intensively weathered till ('Zeiningen-Till')

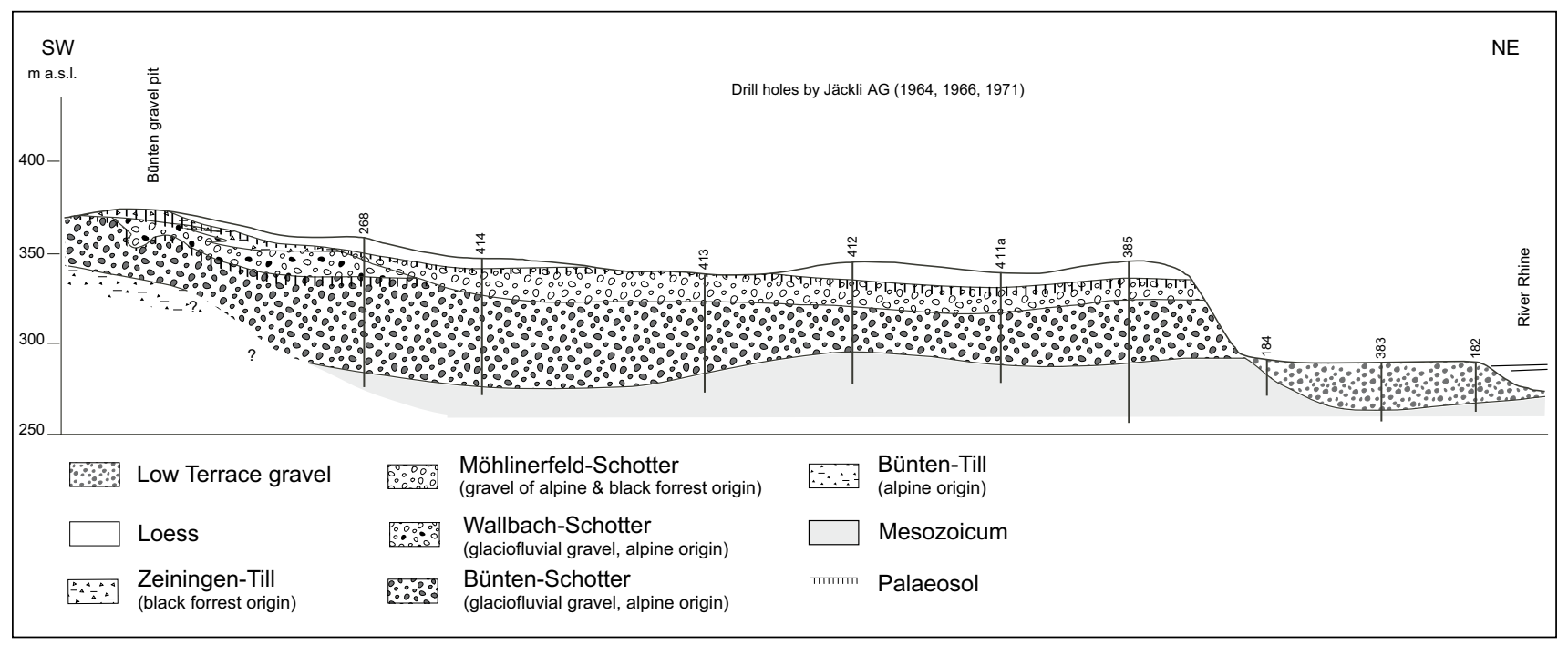

Fig. 5: Geological situation at Möhlinerfeld (Möhlin glaciation; modified after GRAF 2009a)

Abb. 5: Geologische Verhältnisse auf dem Möhlinerfeld (Möhlin-Eiszeit; modifiziert nach GRAF 2009a). 
found in the southern part of the area, outcropping in the Bünten gravel pit. Petrography of this unit indicates an origin from the Wehra Valley, and indicates an advance of the Black Forest Glacier that reached all over Möhlinerfeld, and probably causing deformation of the two oldest gravel units mentioned above. The youngest unit consist of loess deposits with a thickness of up to $10 \mathrm{~m}$.

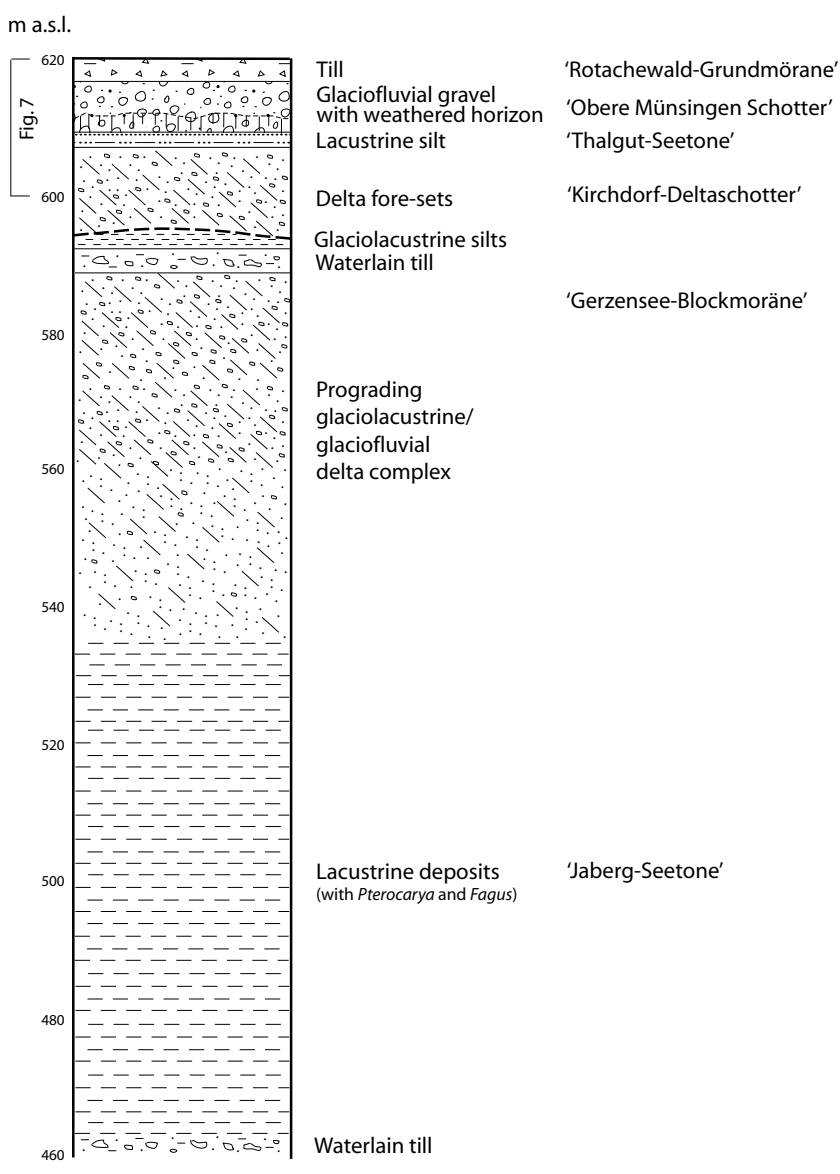

Fig. 6: Geological record of the Thalgut gravel pit and scientific drilling (redrawn after SCHLÜCHTER 1989a,b).

Abb. 6: Geologische Abfolge in der Kiesgrube und Forschungsbohrung Thalgut (umgezeichnet nach SCHLÜCHTER 1989a,b).
Despite the fact that the original interpretation of the surface morphology representing two moraine ridges of the Most Extensive Glaciation (PENCK \& BRÜCKNER 1901/09) is contradicted by the sedimentological evidence (the ridges are entirely made up of loess), this area represents evidence of the furthest extent of alpine glaciation ('Bünten-Till'), the Möhlin Glaciation.

\subsubsection{Aare Valley}

This region comprises the middle reaches of the River Aare, i.e. the area between the margin of the Alps at Lake Thun and the narrows near the town of Olten, where the Aare for some part flows through Jurassic limestone (Fig. 1). For this article, evidence from sites in adjacent regions in Seeland, the Jura Mountains and the midlands of Emmental are included in this section.

The sequence in the Thalgut gravel pit (Fig. 1) and its downward extension in a scientifically executed drill hole represent one of the most complex Quaternary succession of the Swiss lowlands (Fig. 6; SCHLÜCHTER 1987a, 1989a, b). The lowest unit reached in the drill hole is composed of glacial sediments deposited in a lake (water-lain till), passing in to lacustrine deposits ('Jaberg Seetone'). The latter unit contains an interglacial pollen assemblage with a dominance of Fagus (beech, up to $58 \%$ ) and a prominent presence of Pterocarya (wingnut, up to $7 \%$ ) (WELTEN 1988). The lacustrine deposits are interpreted as bottom-sets and develop into the fore-sets of a prograding delta. In the upper part the fore-sets have a glacial character, as is indicated by the presence of boulders and diamictic, subaquatic mudflows. The top-sets of the delta sequence consist of coarse boulders and are covered by a subaquatically deposited till. The lake basin persisted after ice retreat, as is documented by deposition of laminated sandy silt. These fine-grained sediments are cut by an erosional surface showing a pronounced palaeo-relief. Soil development associated with this discontinuity is interpreted to represent at least one well-developed warm period. Coarse delta gravel was later deposited filling up the existing relief ('Kirchberg-Deltaschotter'), and it is interesting to note that deposition was

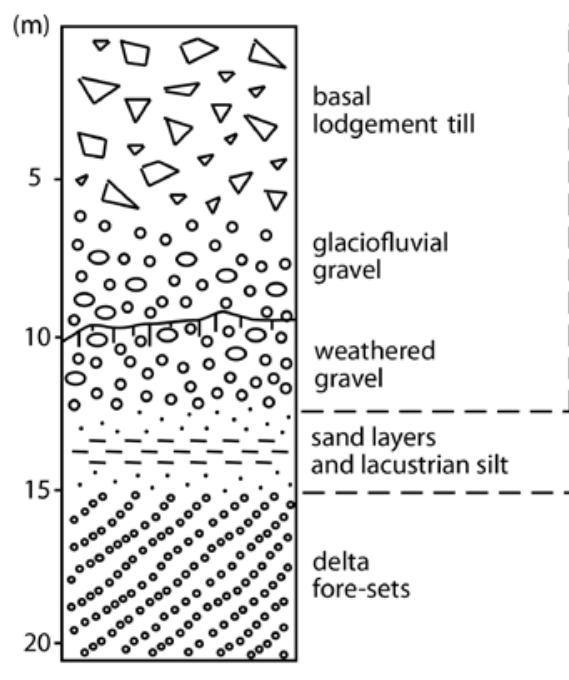

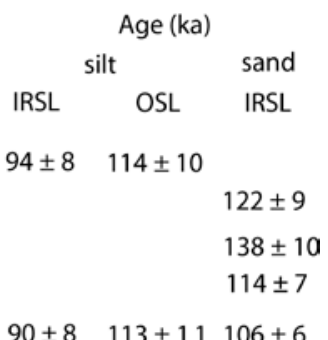

$130 \pm 10149 \pm 13$

$127 \pm 12 \quad 135 \pm 14$

$136 \pm 14 \quad 138 \pm 14$

$125 \pm 12 \quad 132 \pm 12$

$125 \pm 12 \quad 135 \pm 13$
Fig. 7: Upper part of the Thalgut section with luminescence ages (from PREUSSER \& SCHLÜCHTER 2004).

Abb. 7: Oberer Teil des Profils von Thalgut mit Lumineszenzalter (aUS PREUSSER \&

$\begin{array}{ll}\because \therefore 0 & \text { zalter (aUS PREUSSE } \\ & \text { SCHLÜCHTER 2004). }\end{array}$ 


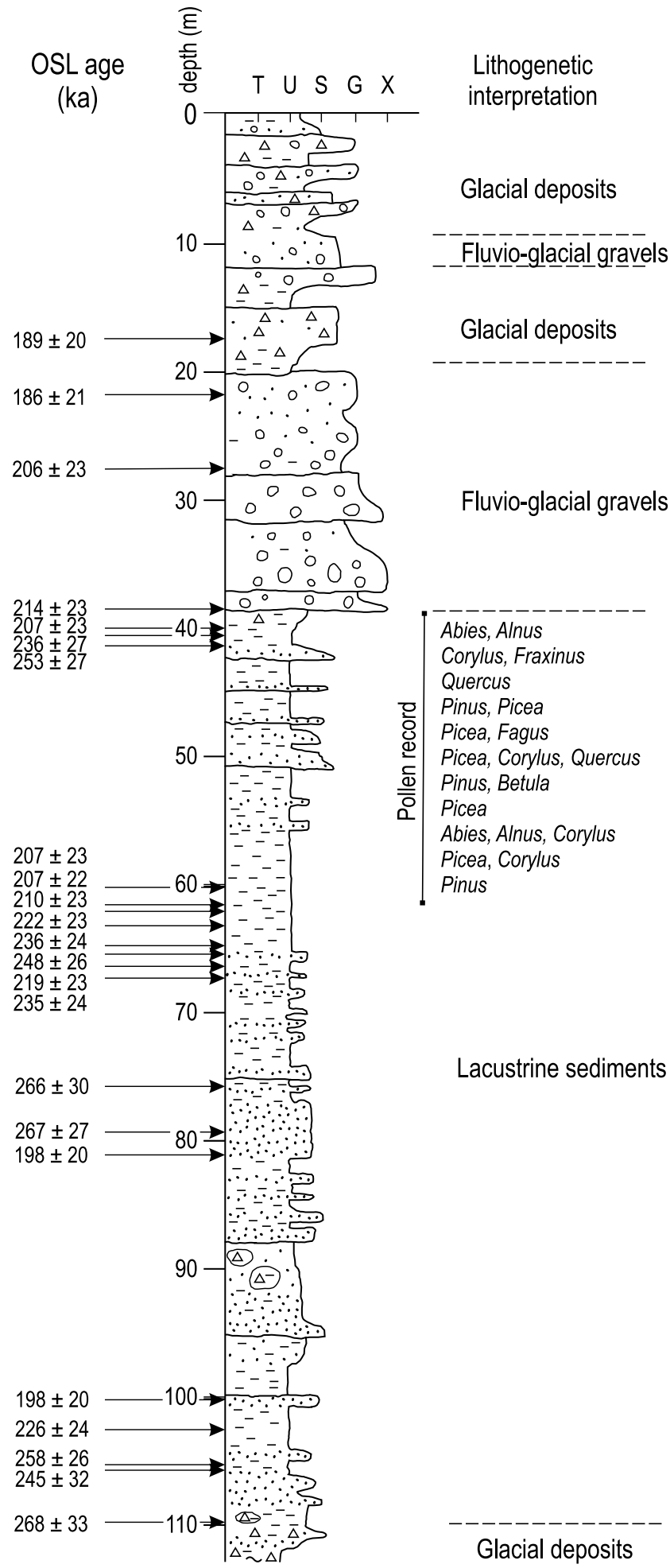

Fig. 8: The geological record of the Meikirch 1981 scientific drilling with OSL ages and major pollen zones (modified after PREUSSER et al. 2005).

Abb. 8: Geologische Abfolge der Forschungsbohrung Meikirch 1981 mit OSL Altern und Hauptpollenzonen (verändert nach PREUSSER et al. 2005).

by a stream almost perpendicular to the present drainage direction. The pebbles are re-worked Molasse bedrock and show few components from the Helvetikum and the Central Alps, implying that the gravel was not deposited by the Rivers Aare, Kander, or Simme. From the sedimentological point of view a close presence of a glacier during deposition appears unlikely. In its upper part, the gravel shows a concordant transition via a sandy layer into silt ('Thalgut Seetone') (Fig. 7). Based on pollen analysis and luminescence dating, this basin deposit is correlated with the Last Interglacial (Eemian) (Welten 1982; Preusser o SCHLÜCHTER 2004). In parts of the gravel pit weathered gravel was situated at the top of the basin deposits, mainly eroded during deposition of the next gravel unit ('Obere Münsingen Schotter'). The youngest gravel unit is topped by basal till ('Rotachewald-Grundmoräne), correlated with the Last Glaciation of the area (SCHLÜCHTER 1989a, b). The weathered gravel above the basin deposits are, based on the petrography, interpreted to result from a glacier advance beyond the margin of the Alps. The age of this advance has to be younger than Eemian but must be significantly older than the last advance, as it shows intense weathering. Luminescence dating of sandy sediments on top of the interglacial deposits implies that the weathered gravel unit was probably deposited during an early phase of the last glacial cycle (Preusser \& SchlüChter 2004).

Another important stratigraphical record of the Aare Valley is the scientific drill hole near Meikirch, north of Bern (Fig. 1). Here, fine-grained lake sediments are found below ca. $40 \mathrm{~m}$ of coarse-grained melt water deposits (Fig. 8). The lake sediments (ca. $70 \mathrm{~m}$ ) are situated on top of glacial deposits (till). Detailed pollen analyses revealed evidence for three warm periods within the lake deposits, separated by two cold phases (WELTEN 1982, 1988). Based on luminescence dating and re-interpreting the original palynostratigraphy, Preusser et al. (2005) correlate these three warm phases, each of which represents interglacial environmental conditions, with Marine Isotope Stage (MIS) 7 (242-186 ka).

'Höhenschotter', glaciofluvial gravel situated in elevated morphological positions, are considered as the oldest Quaternary deposits of the middle and upper Emmental (GERBER 1941) (Fig. 1). The sediments are found as relicts of partially cemented former channel fills and delta deposits on top of Molasse bedrock (Gerber 1950; Gruner 2001). The gravel is mainly composed of pebbles originating from the Aare Glacier, but also partially contains material derived from the Valais, mainly in the till on top of the glaciofluvial deposits. From its morphological position, sedimentation occurred during a glaciation of greater extent than the Last Glaciation, and has been considered to be older than Eemian. This minimum age estimate is supported by U/Th dating of calcite precipitates from the Landiswil gravel pit (DEHNERT et al. 2010). Infrared stimulated luminescence (IRSL) dating of sandy parts of the delta deposits at the same site gave two ages of $153 \pm 16 \mathrm{ka}$ and $160 \pm 14 \mathrm{ka}$ (DEHNERT et al. 2010).

In the Jura Mountains, erratic boulders are found outside the limits of the Last Glaciation. Without any age control, these deposits have been tentatively correlated with either the Rissian Glaciation of PENCK \& BRÜCKNER (1901/09) or the Most Extensive Glaciation, thought to be older than $700 \mathrm{ka}$ (SCHLÜCHTER \& KeLly 2000). A first study applying ${ }^{10} \mathrm{Be}$ and ${ }^{21} \mathrm{Ne}$ surface exposure dating to four selected boulders from the Montoz anticline resulted in ages between ca. $70 \mathrm{ka}$ and $170 \mathrm{ka}$ (GRAF et al. 2007). The younger ages of this data set were determined from two boulders of smaller size that had probably rotated in the past. As a consequence, GRAF et al. (2007) consider it more likely that the larger boulders reflect the age of deposition. Using a conservative 


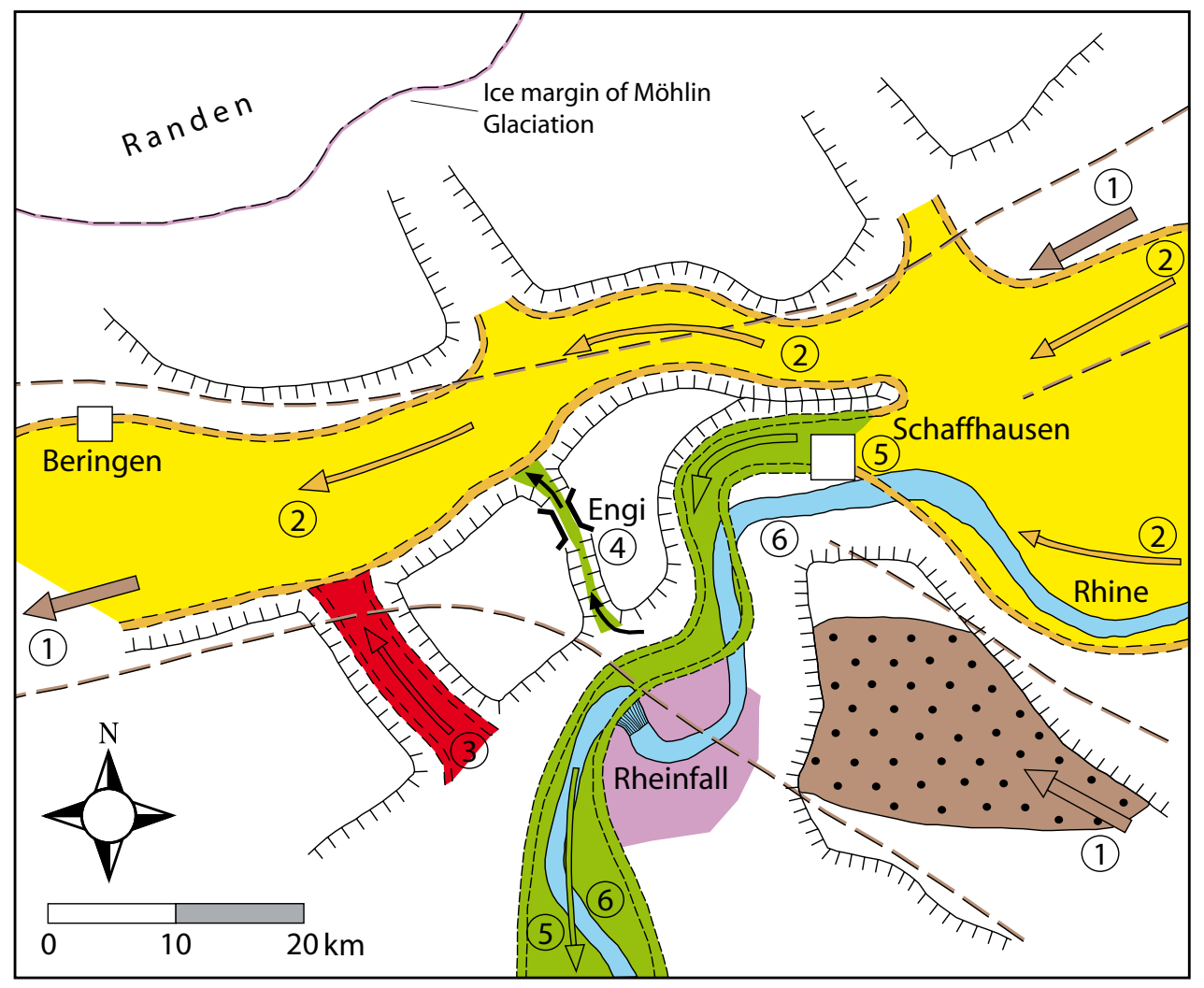

Fig. 9: Pleistocene troughs in the area Schaffhausen-Klettgau (modified after KELLER \& KRAYSS 2010). 1: Upper Klettgau trough ('Tiefere Deckenschotter'), 2: Main Klettgau trough (Möhlin to Habsburg), 3: Neuhauserwald trough (Habsburg to Beringen), 4: Engi trough (Beringen, Birrfeld maximum), 5: Rheinfall trough (late Beringen to Birrfeld), 6: Present Rhine trough (since late Birrfeld).

Abb. 9: Pleistozäne Rinnen im Raum Schaffhausen-Klettgau (modifiziert nach KELLER \& KRAYSS 2010). 1: Obere Klettgau Rinne (Tiefere Deckenschotter), 2: Klettgau Hauptrinne (Möhlin bis Habsburg), 3: Neuhauserwald Rinne (Habsburg bis Beringen), 4: Engi Rinne (Beringen, Birrfeld Maximum), 5: Rheinfall Rinne (spätes Beringen bis Birrfeld), 6: Heutige Rinne des Rheins (seit spätem Birrfeld).

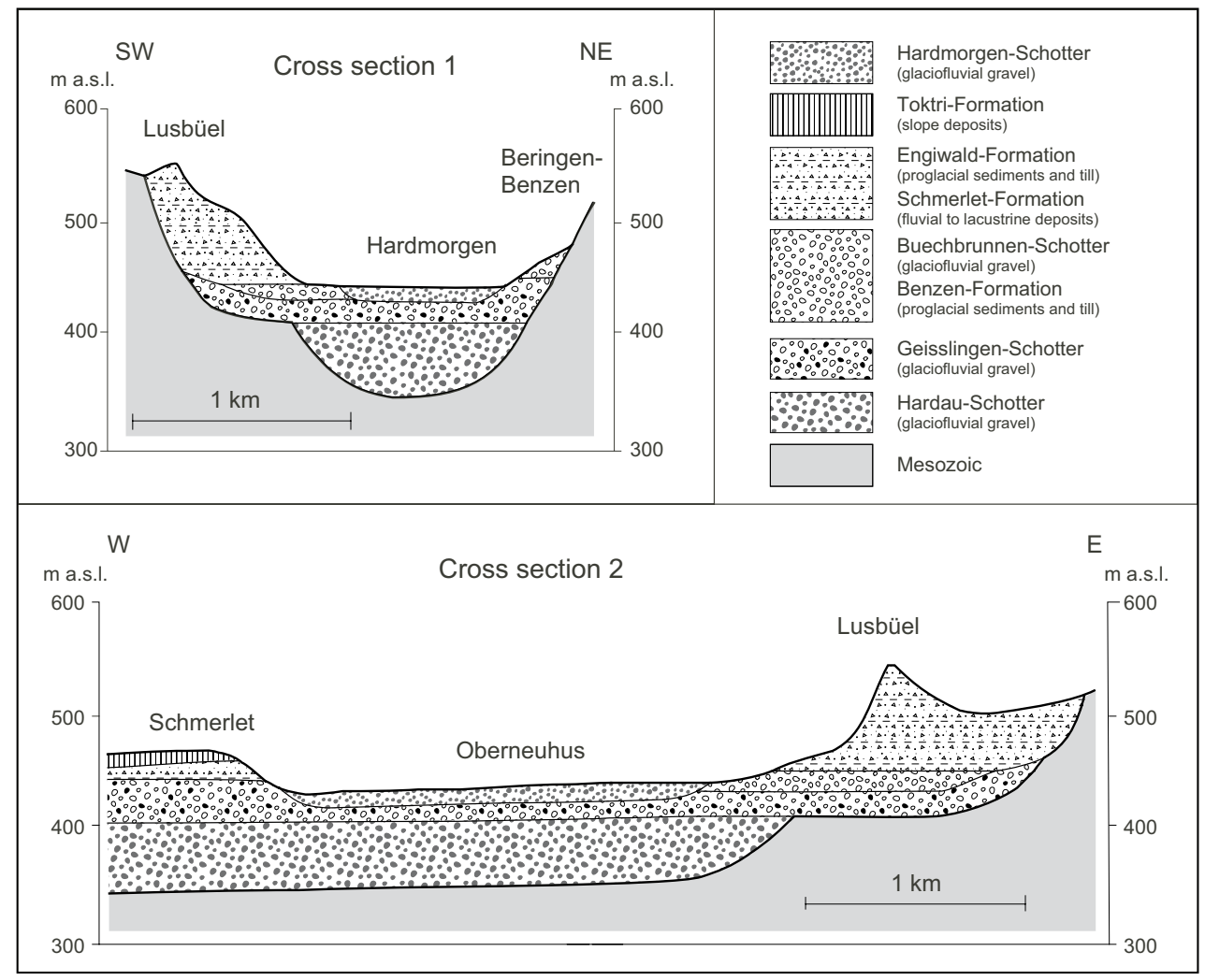

Fig.10: Two cross sections through the Klettgau Valley (modified after GRAF 2009a).

Abb. 10: Zwei Querschnitte durch das Tal des Klettgau (modifiziert nach GRAF 2009a). 
erosion rate of $3.0 \pm 0.5 \mathrm{~mm} \mathrm{a}^{-1}$ results in age estimates of $143 \pm 17 \mathrm{ka}\left({ }^{10} \mathrm{Be}\right)$ and $124 \pm 12 \mathrm{ka}\left({ }^{21} \mathrm{Ne}\right)$, and of $163 \pm 21 \mathrm{ka}$ $\left({ }^{10} \mathrm{Be}\right)$ and $138 \pm 13 \mathrm{ka}\left({ }^{21} \mathrm{Ne}\right)$, respectively.

The gravel pit Finsterhennen is situated in the western part of the Aare Valley, also known as Seeland (Fig. 1). Exposed in this pit are till and pro-glacial meltwater deposits attributed to the Last Glaciation of the Swiss lowlands. The radiocarbon age of a mammoth tusk of $25^{\prime} 370 \pm 190{ }^{14} \mathrm{C}$ yr (29'650-30'640 cal. BP) from the middle part of the glaciofluvial sediments is confirmed by Optically Stimulated Luminescence (OSL) ages of $28.5 \pm 2.3 \mathrm{ka}$ and $28.9 \pm 2.5 \mathrm{ka}$ (Preusser et al. 2007). Interestingly, OSL dating of glaciofluvial sediments from below a residual till in the lower part of the exposure gave an age of $76 \pm 6 \mathrm{ka}$, indicating an ice advance of the Valais Glacier to this point during late MIS 5 or early MIS 4.

Near the village Wangen an der Aare, two separated terminal moraine ridges are present, known as older and younger Wangen stage. The inner and hence younger stage has traditionally been correlated with the Last Glaciation and this assumption is confirmed by surface exposure dating of a large boulder near Steinhof (Fig. 1), giving a mean age of $20.1 \pm 1 \mathrm{ka}$ (Ivy-OcHs et al. 2004). The age of the outer ridge is not known but loess-like cover sediments on top of the glacial deposits indicate that the glaciation responsible for the formation of the ridge has to be older than the Last Glaciation (MAILÄNDER \& VEIT 2001). However, whether this represents an early Late Pleistocene glacial advance (e.g. MIS 4), an equivalent of MIS 6, or an even older glaciation, remains to be investigated.

\subsubsection{Klettgau}

The present dry valley of Klettgau (Fig. 1) was during most of the Pleistocene part of the Rhine Valley before the river changed its course towards the south near the city of Schaffhausen (Fig. 9). Relicts of 'Tiefere Deckenschotter' and some minor remnants of 'Höhere Deckenschotter' are found in marginal parts of the valley. From gravel petrography these deposits indicate an origin from the Lake Constance-Rhine Glacier system, and document the active course of the River Rhine during most of the Pleistocene. The sediments of the valley bottom represent High Terrace deposits from the morphological point of view (GRAF 2009a).

The channel of Oberklettgau, with a base at $340 \mathrm{~m}$ a.s.l., contains a complex sedimentary fill (Fig. 10). The sequence starts with glaciofluvial sediments ('Hardau-Schotter') that reach a thickness of up to $150 \mathrm{~m}$. The gravel originates from the Lake Constance-Rhine Glacier, although the presence of ice in Klettgau is not documented for the time of gravel formation (GRAF 2009a). An erosional trough was later incised into the gravel down to a level of $410 \mathrm{~m}$ a.s.l. In addition to the erosion along the valley axis, another channel originating from the south incised at the same time. This trough was later filled by glaciofluvial gravel ('GeisslingenSchotter'), with deposition in the eastern part originating from the Lake Constance-Rhine glacier, and in the southern channel from the Walensee branch of the Rhine glacier. The maximum ice extent during this phase (Hagenholz advance) was about $25 \mathrm{~km} \mathrm{SE}$ of Klettgau, close to the present airport of Zurich (GRAF 2009a).
The following phase of sedimentation (Beringen Glacial) is characterised by the direct presence of glaciers in Oberklettgau. The presence of the two branches of Rhine glacier (Lake Constance, Walensee) in the region is evidenced by petrography of the gravel. The ice reached towards the present village of Löhningen and left tills in the marginal areas of Oberklettgau, fluvial sand and gravel down-valley, and fine-grained sediments in smaller side valleys ('Buechbrunnen-Schotter' and 'Benzen-Formation'; Fig. 10). Sedimentary evidence reveals that the glaciation comprises two advances separated by a phase of ice retreat. First results of IRSL dating imply an age of ca. 150 ka for the first ice advance towards the Klettgau (Preusser \& Graf 2002; Graf 2009a). Glaciers left complex sedimentary successions in the Rhine trough and the southerly channel, comprising till, lake deposits and gravel ('Engiwald-Formation' and 'Schmerlet-Formation'), was not eroded during ice meltdown. Partial erosion in Oberklettgau was caused by meltwater flowing through a small valley (Engi). Later, meltwater discharge shifted to the south, causing initial incision of the present course of the River Rhine. This newly formed erosional channel was later, probably during a temporal re-advance within general ice retreat, filled with $60 \mathrm{~m}$ of glaciofluvial gravel ('Schaffhausen-Schotter'). The mean IRSL age for this unit is about $130 \mathrm{ka}$ (Preusser \& GrAF 2002; GrAF 2009a). The above mentioned small valley was again used by meltwater during the maximal ice extent of the Last Glaciation, causing the deposition of $10 \mathrm{~m}$ gravel ('Hardmorgen-Schotter') in Oberklettgau.

\subsubsection{Birrfeld}

Located in the lower Reuss Valley, Birrfeld is bounded by Molasse hills in the east and west, by the Mesozoic Lägern structure to the north, and by the hills of Habsburg to the NE (Fig. 1). Bedrock surface is characterised by an overdeepened basin to the south of the Lägern and by two channels heading northward across the Mesozoic structure, all of which are attributed to subglacial erosion (GRAF 2009a). To the NW of Birrfeld, a palaeo-channel turns below the hill of Habsburg from SW to N. The Habsburg palaeo-channel contains the oldest sediments of the region, comprising lacustrine sediments and till, probably reflecting deposition during the Möhlin advance. On top are up to $100 \mathrm{~m}$ thick gravel deposits ('Habsburg-Schotter'), intercalating with glacial sediments and subglacial gravel in the southern part of the basin (Fig. 11). These deposits are attributed to the Habsburg glaciation.

The next phase of accumulation is documented by glacial deposits and basin sediments. This Remigen advance of the Beringen glaciation reached far beyond Birrfeld and formed two channels crossing the Lägern structure. Glacial ('Hausen-Till') and associated proglacial gravel ('Remigen-Schotter') deposits of this advance are found on top of 'Habsburg-Schotter' (Fig. 11). The two channels contain basin sediments in glaciolacustrine ('Hausen-Lehm', Fig. 11) and partially in sandy facies ('Reusstal-Sand', Fig. 12). 'LupfigSchotter', found in channels incised into the basin sediments in the western part of the region, is interpreted to represent a re-advance during the meltdown phase of the Remigen advance. This unit is covered by a well-developed palaeosol (Fig. 12), which may represent the Last Interglacial. 


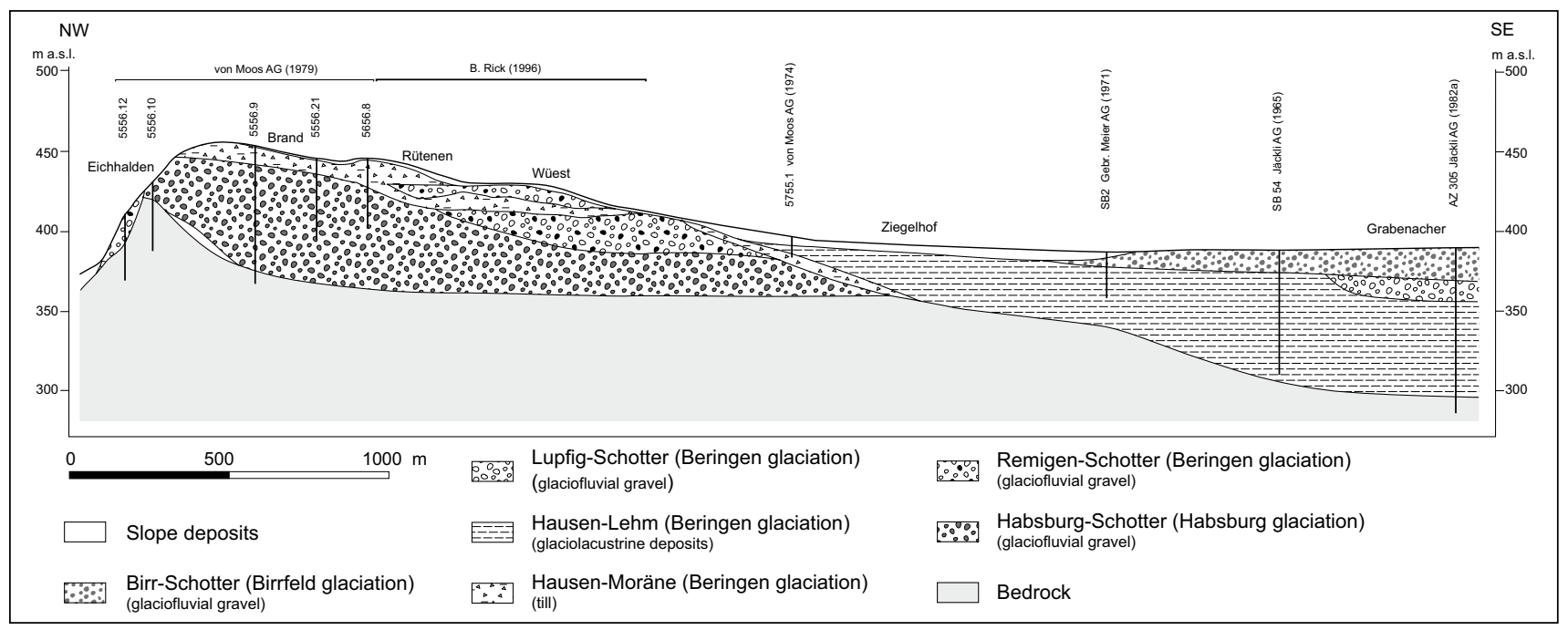

Figure 11: Geological situation in the surroundings of Habsburg hill (modified after GRAF 2009a).

Abbildung 11: Geologische Verhältnisse im Umfeld des Habsburgs Hügels (modifiziert nach GRAF 2009a).

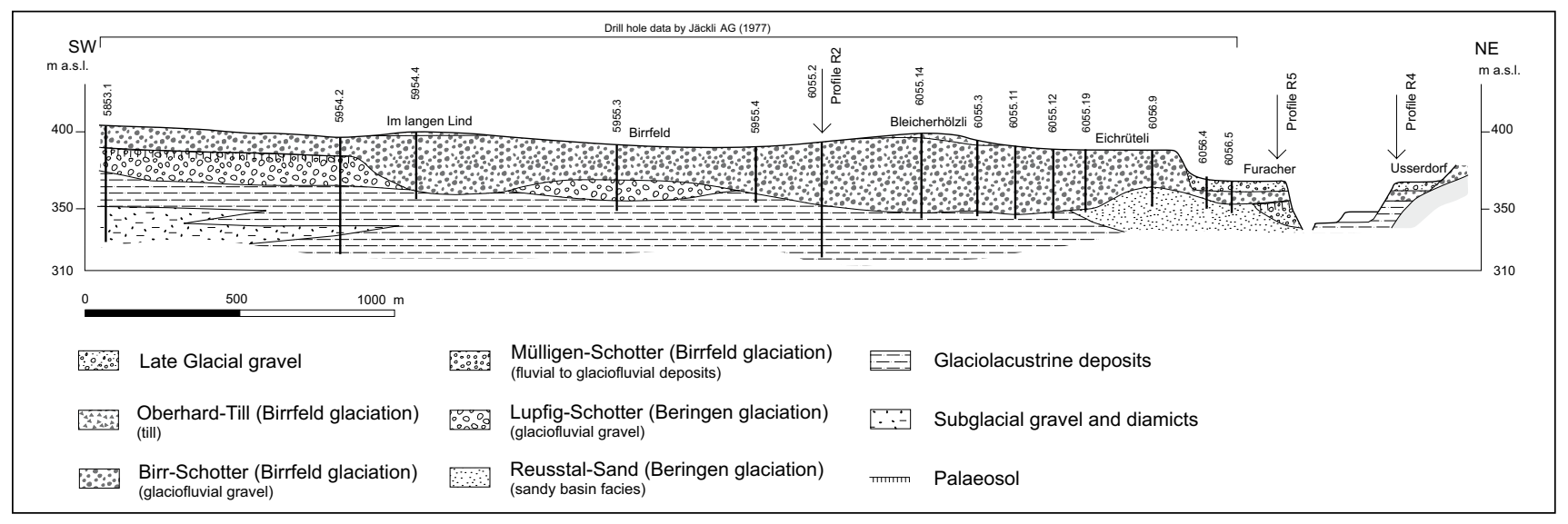

Fig. 12: Geological situation at Birrfeld (modified after GRAF 2009a)

Abb. 12: Geologische Verhältnisse im Birrfeld (modifiziert nach GRAF 2009a).

Along the slopes of the present Reuss Valley, fluvial deposits changing into glaciofluvial sediments ('Mülligen-Schotter') on top of 'Reusstal-Sand' have been dated by IRSL to $73 \pm 11 \mathrm{ka}$ and $55 \pm 14 \mathrm{ka}$ (Preusser \& GRAF 2002). This glacial ice advance, however, did not reach Birrfeld. The gravel bears a weakly developed palaeosol.

The first advance of the Last Glaciation is mainly documented by glacial deposits along the present Reuss Valley (Lindmühle advance). After temporal ice retreat glaciofluvial gravel forming the present land surface has been deposited ('Birr-Schotter', Fig. 11, Fig. 12). This unit is partly found on a paleosol developed on the gravel of the Beringen glacial ('Lupfig-Schotter'), and intercalates with glacial deposits that partly formed flat hills of till ('Oberhard-Till', Fig. 12). Different stages of ice meltdown are represented by thin gravel units along the Reuss Valley (Fig. 12).

\subsubsection{Linth Basin}

The $15 \mathrm{~km}$ long and $7 \mathrm{~km}$ wide Linth Basin is located directly at the margin of the Alps, and spreads towards the north from the junction of Walensee and Linth Valley (Fig. 1).
Two Molasse inselbergs subdivide the Linth Plain between Walensee and Lake Zurich. Older glacial deposits are long known from Buechberg and Kaltbrunn (BROCKMANNJeroch 1910; JeAnNet 1923; Welten, 1988). In his compilation of the Quaternary of the Linth area ScHINDLER (2004) describes the sedimentary sequences in detail, and it is interesting to note that he refers to two independent 'Riss' glaciations. A summary of the sedimentary sequence of Buechberg and Kaltbrunn-Uznach is given in Figure 13, and the presence of lacustrine deposits at the same altitude is important for correlation between the two outcrops.

During the oldest preserved glaciation, the Linth Glacier carved out a substantial basin into Molasse bedrock at the northern margin of the Alps. According to the drill hole at Tuggen, the surface of bedrock in the middle of that basin is probably at a depth of about $100 \mathrm{~m}$ a.s.l. (SCHINDLER 2004). During meltdown of this glaciation a lowermost till was deposited and a lake subsequently developed, in which delta sediments have been deposited ('Günterstall Deltaschotter'). The sediments were derived from local streams and the interglacial character of deposition is documented by plant macro remains (Brockmann-Jerosch 1910). The delta is cut by till 


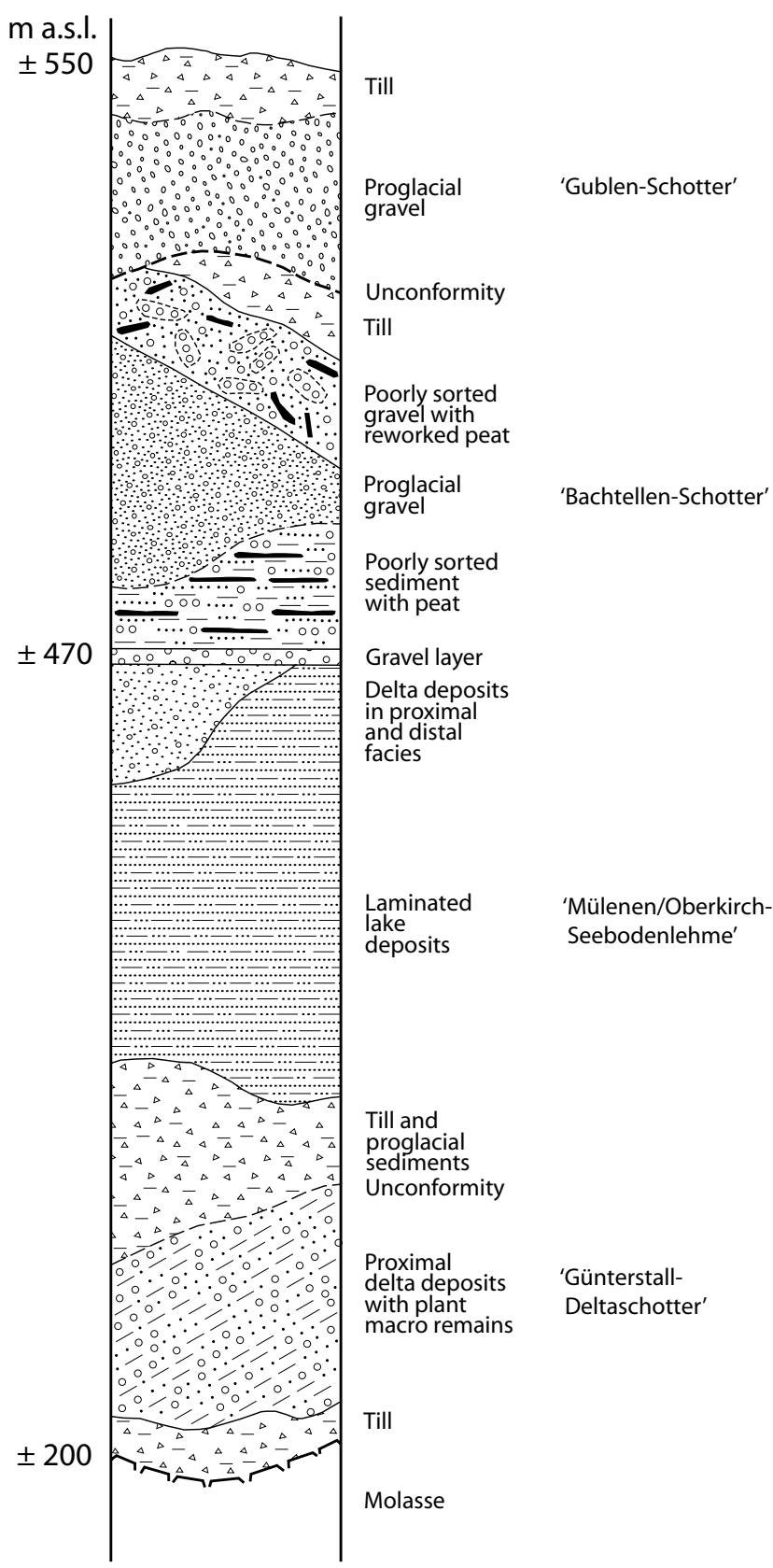

Fig. 13: Geological composite section of the Linth Basin (modified after KELLER \& KRAYSS 2010).

Abb. 13: Geologisches Sammelprofil der Linthbecken (modifiziert nach KELLER \& KRAYSS 2010).

documenting a next glacial advance into the Linth Basin. The till reaches a thickness of up to $50 \mathrm{~m}$ and its base has been found in drilling down to a depth of $300 \mathrm{~m}$ a.s.l., indicating deep erosion in the central part of the basin. Laminated grey lake deposits then follow and reach a thickness of up to $150 \mathrm{~m}$, as found in drill holes up to $100 \mathrm{~m}$ below the present surface of the Linth Plain. They are found over a distance of more than $30 \mathrm{~km}$ from Buechberg to the middle reaches of Walensee. In its upper parts, the lake deposits bear plant remains and pollen of boreal trees and Alnus (alder), indicating that the lake represents a late glacial period of a preceding glaciation (WELTEN 1988). The lake deposits are overlain by a horizontal gravel layer, indicating a lake surface at $470 \mathrm{~m}$ a.s.l. In the western part of Buechberg, delta deposits with peb- bles originating from the Linth Glacier catchment are found within the lake deposits.

The next higher unit ('Bachtellen-Schotter') shows a coarsening upwards tendency and partially non-orientated deposition and disturbances. The unit is interpreted to represent an ice-marginal position and proglacial sediments of an ice-advance. Above an unconformity, unsorted gravel and sand follow with irregularly admixed pieces of peat and gravel layers, the later originating from the unit beneath. These deposits likely represent sediments reworked by an advancing glacier. Lodgement till, although not present in all outcrops, documents that the region was overrun by the Linth Glacier during this advance. A pronounced unconformity on top of the till is probably of an erosional nature and likely reflects interglacial conditions. The next glacial advance is documented by coarsening upward ice-marginal gravel deposits ('Gublen-Schotter') that are erosionally cut and covered by till. The latter, uppermost unit continuously covers the valley flanks and inselbergs of the Linth Basin and is supposed to represent the Last Glaciation of the area.

\subsubsection{Glatt Valley}

The lower Glatt Valley spreads over $40 \mathrm{~km}$ from the Molasse ridge of Hombrechtikon (near Rapperswil at Lake Zurich) via Kloten and Bülach to the River Rhine (Fig. 1). Beside some hills made up by Molasse, the entire valley is characterised by outcropping deposits of the Last Glaciation. A series of drill holes gave insights into the composition of the Quaternary basin fills of this region. Glatt Valley is a typical overdeepened foreland basin with bedrock altitudes of 200-300 $\mathrm{m}$ a.s.l. in the eastern main branch, and ca. $350 \mathrm{~m}$ a.s.l. in the small western branch. The occurrence of older basin deposits is along the main branch of the trough between Greifensee and Pfäffikersse (Fig. 1) (HaLdimanN 1978; Wyssling \& WyssLing 1978; Welten 1982; KempF 1986; WYSSLING 2008; GRAF 2009a)

The composite sketch of the basin fills (Fig. 14) shows that the sediment succession in the main basin is subdivided by a prominent unconformity into a central and a western part. Besides the main basin, the sub-basins of Greifensee and Pfäffikersee are found to the west and east, respectively. The main basin (Fig. 14) has a bedrock depth of about $300 \mathrm{~m}$ a.s.l. in the middle part of Glatt Valley, and reaches as low as $250 \mathrm{~m}$ a.s.l. The bottom of the trough is filled by till and partially covered by ice-decay meltwater deposits. All over the central parts of Glatt Valley, laminated lake sediments with a thickness of 100-150 m on top of the till are interpreted to represent varved late glacial deposits. Along the central basin axis between Greifensee and Pfäffikersee gravel deposits occur that reach a thickness of $30 \mathrm{~m}$ and are partially cemented ('Aathal-Schotter'). These sediments are exposed in the Aa Valley but have also been found in drillings farther north, up to the village of Kloten. Plant remains and debris of snails found in the basal part of the gravel imply a warm period preceding the deposition of the gravel. In its upper part, the gravel contains lenses of till that are interpreted to represent an advancing glacier. The unit is expected to represent proglacial sediments because it is actually covered by till. An unconformity docu- 


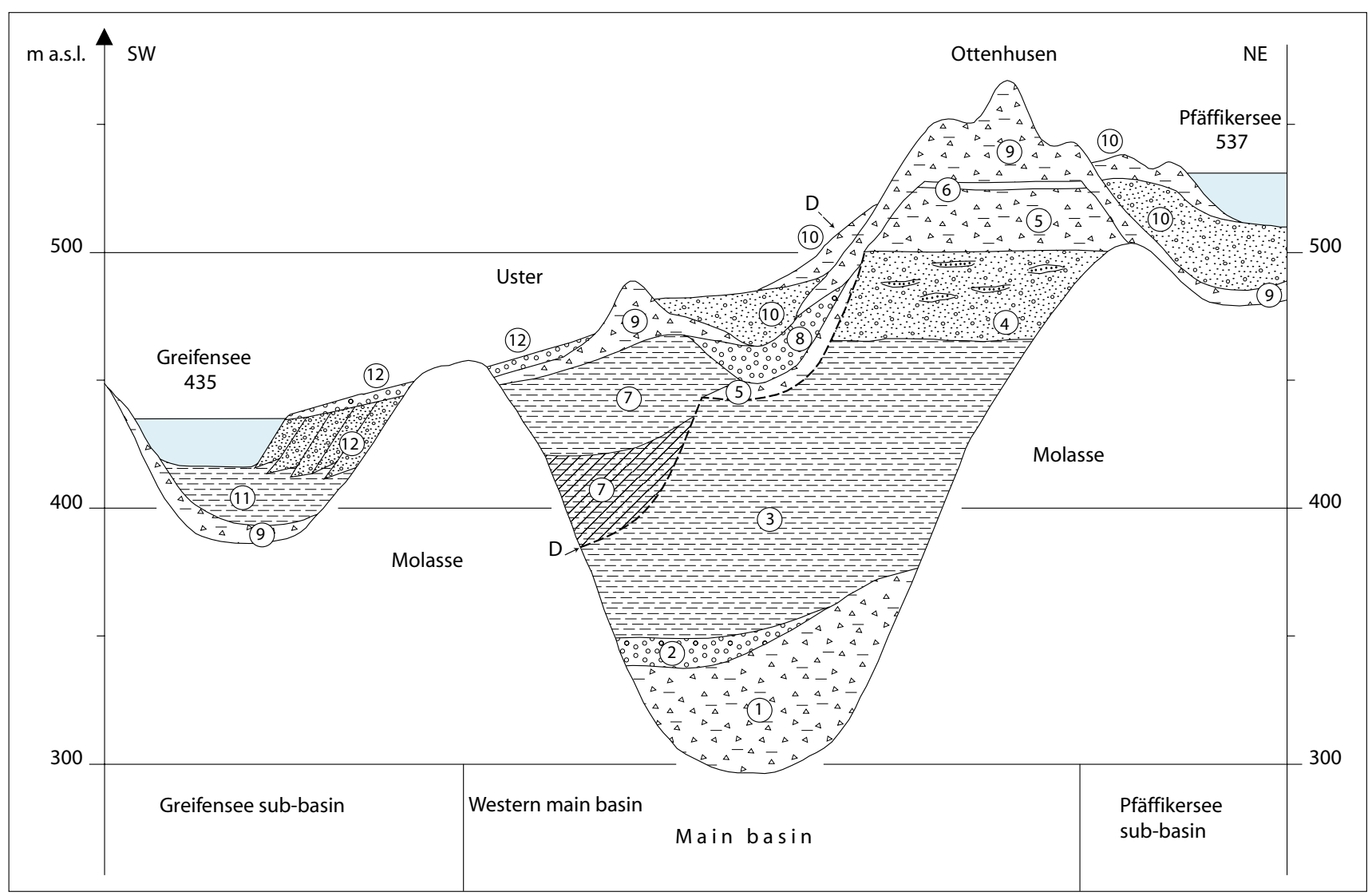

Fig. 14: Geological cross section of the Upper Glatt Valley (modified after GRAF 2009a and KELLER \& KRAYSS 2010). 1: Till, 2: meltwater deposits, 3: laminated lacustrine sediments, 4: pro-glacial gravel; basal part bearing plant remains; upper part containing lenses of till; 'Aathal-Schotter', 5: till, 6: unconformity, 7: lake sediments; basal part bearing plant remains, 8: gravel, 9: till, 10: gravel and till of the final phase of the Last Glaciation, 11: lake sediments, 12: post-glacial deposits.

Abb. 14: Geologisches Querprofil durch das obere Glatttal (modifiziert nach GRAF 2009a und KELLER \& KRAYSS 2010) 1: Till, 2: Schmelzwasserablagerungen, 3: laminierte Seesedimente, 4: Vorstossschotter; mit Pflanzenresten im basalen Teil; Linsen von Till im oberen Teil, 'Aathal-Schotter', 5: Till, 6 : Diskordanz, 7: Seesedimente; Pflanzenreste im basalen Teil, 8: Schotter, 9: Till, 10: Schotter und Till der finalen Phase der letzten Vergletscherung, 11: Seesedimente, 12: Postglaziale Ablagerungen.

mented by sand and silt separates this lower from an upper till unit attributed to the Last Glaciation.

The western main basin (Fig. 14) is characterised by a deep-reaching unconformity, cutting the upper part of the lake sediments. It is partly covered by till and indicates glacial erosion of the trough. The western part of the basin comprises lake sediments rich in plant remains and bearing Eemian pollen assemblages (WeLten 1982). The lake deposits are mainly covered by gravel and till of the last glacial advance, but at Gossau (Fig. 1) a complex succession of the early and middle part of the Birrfeld glaciation had been exposed (SCHLÜCHTER et al. 1987). Luminescence dating indicates that delta deposits at Gossau, interpreted to result from a glacial advance, where deposited at the very beginning of the Birrfeld glaciation, c. 105 ka ago (Preusser 1999; Preusser et al. 2003). Till of the Last Glaciation is found in the basal and western part of Greifensee sub-basin. Sediments in the Pfäffikersee sub-basin and in the highest parts of the main basin indicate that the glacier re-advanced over the previously deposited gravel and sand during the final phase of the Last Glaciation (Stein am Rhein/Zurich stadial), after temporal ice meltdown. On top of late to post glacial lake sediments a delta was deposited in Greifensee originating from the Aa Valley and Pfäffikersee.

\subsubsection{Rafzerfeld/Thur Valley}

The River Thur flows in a wide valley from east to west and is a tributary of the River Rhine. Beyond the confluence of both rivers, Rafzerfeld is the continuation of the Thur Valley, at a slightly higher altitude, but the structure is almost perpendicularly cut by the Rhine Valley (Fig. 15). Since the mid$20^{\text {th }}$ century several drill holes have brought new insights into the subsurface stratigraphy of this basin area (MüLLER 1996; GRAF 2009a). It is interesting to note that an overdeepened valley reaches from the Thur Valley to the River Rhine, with a NW orientated branch. The deepest parts of this palaeo-channel reach down to sea-level. The sedimentary fill of this trough, however, apparently only comprises sediment accumulation during the Last Glaciation.

Surface relief is characterised by prominent moraine ridges and extended out-wash plains with several gravel pits allowing access to near-surface sediments (Fig. 15). The region is therefore well suited to investigate the landforming processes along the western front of the former Rhine Glacier (Keller \& Krayss 2005a, b; Keller 2005). Ice marginal positions during the Last Glaciation show that the Thur Valley lobe reached Rafzerfeld (Fig. 15), causing the accumulation of out-wash deposits in the area dated 


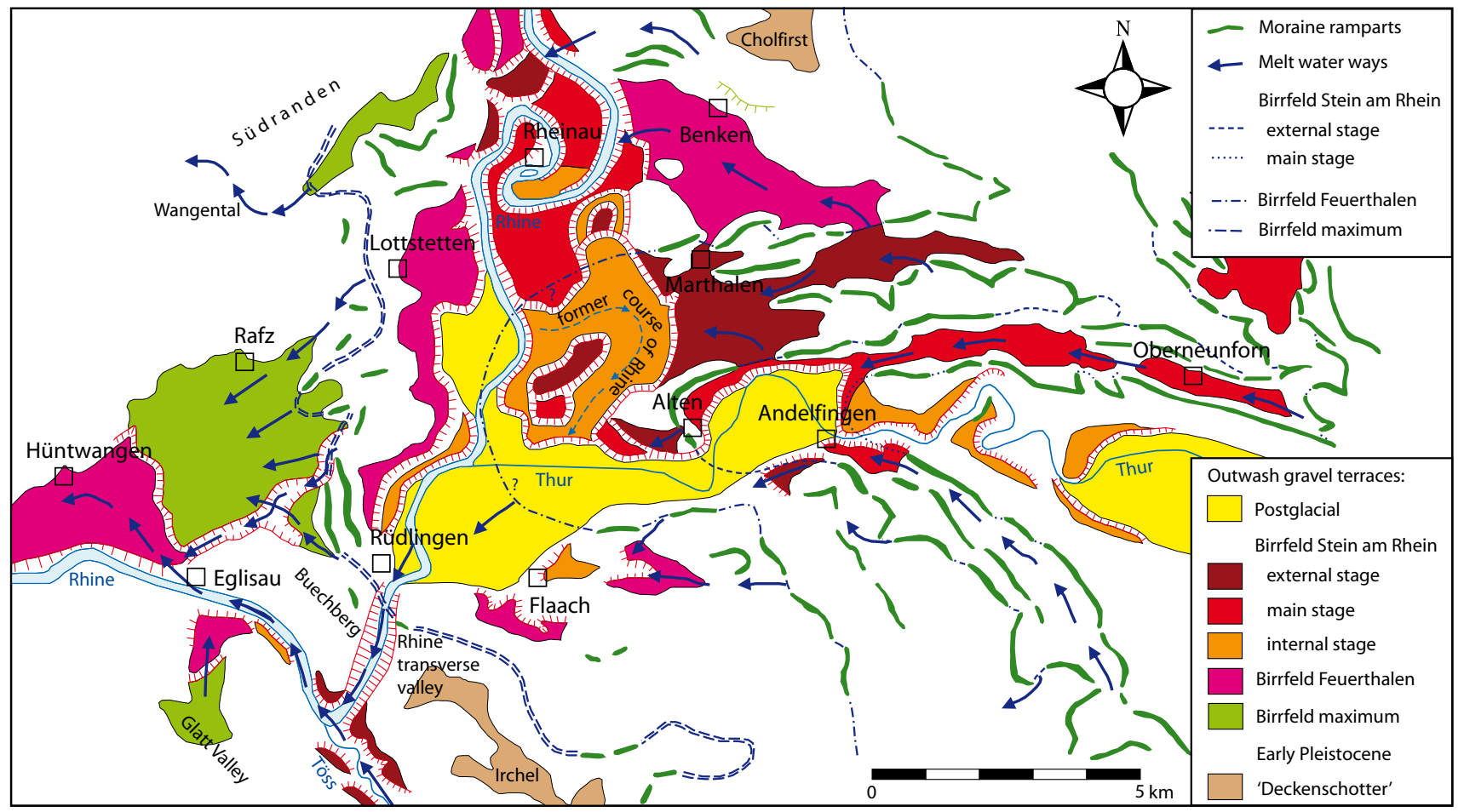

Fig. 15: Geological map of the confluence region of Rivers Rhine and Thur (modified after KELLER 2005).

Abb. 15: Geologische Karte der Konfluenzregion von Rhein und Thur (modifiziert nach KELLER 2005).

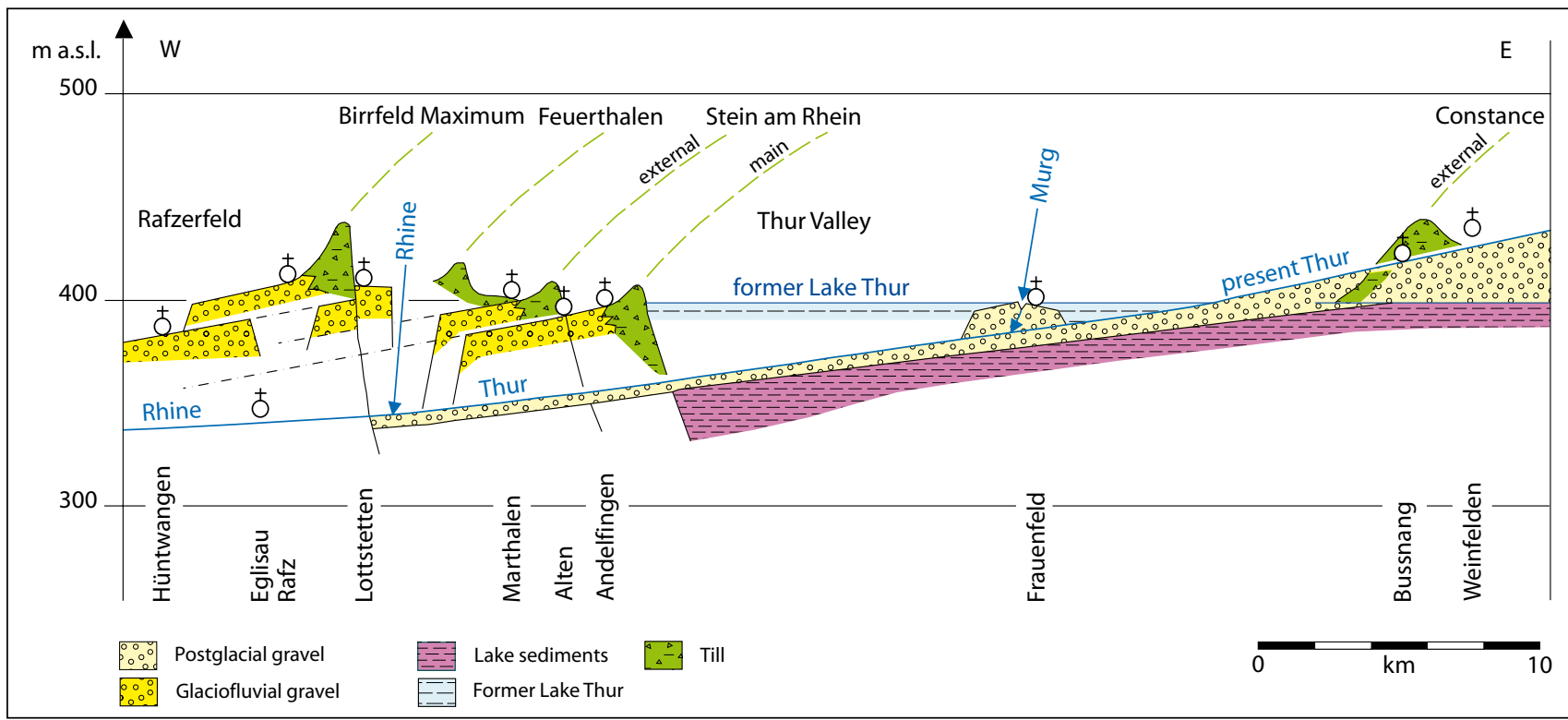

Fig. 16: Geological longitudinal profile of the lower Thur Valley with the location of different ice marginal positions (modified after KELLER \& KRAYSS 1999). Abb. 16: Geologisches Längsprofil durch das untere Thurtal mit der Position verschiedener Eisrandlagen (modifiziert nach KELLER \& KRAYSS 1999).

by both OSL and radiocarbon to being just older than ca. $25 \mathrm{ka}$ (Preusser et al. 2007). Aggradation was so prominent that part of the meltwater spilled over into the Töss Valley. When this drainage became dominant, the River Rhine cut the valley of Rüdlingen-Tössegg into molasse bedrock, and Rafzerfeld finally dried.

With the step-by-step meltdown of the Thur Valley lobe, new outwash plains were established, while the River
Rhine was cutting deeper and forming several terrace levels. The terrace levels can be correlated to individual terminal moraine ridges, with lower terrace levels being related to more internal ice marginal positions.

During a re-advance of the Thur Valley lobe, particularly well developed terminal moraine ridges were formed close to the present village of Andelfingen (Stein am Rhein stadial), followed by a more-or-less continuous meltdown 
towards the Lake Constance basin. In the Thur Valley, a $40 \mathrm{~km}$ long lake established beyond the terminal moraine ridge near Andelfingen (Fig. 16). Due to further deepening of the Rhine Valley between Rüdlingen-Tössegg and the huge sediment input from the hinterland, the lake disappeared after a few thousand years (KeLler \& KrAYsS 1999). The ice-marginal position of Rhine-Linth Glacier has been mapped in detail and reconstructed as three-dimensional ice bodies following glacio-geological aspects (KELLER \& Krayss 2005a). Based on a substantial number of radiocarbon ages for the different ice-marginal positions, the spatial-temporal ice build-up and, in particular, meltdown have been reconstructed for the Last Glaciation (Fig. 17; KeLler \& KRAYSS 2005b).

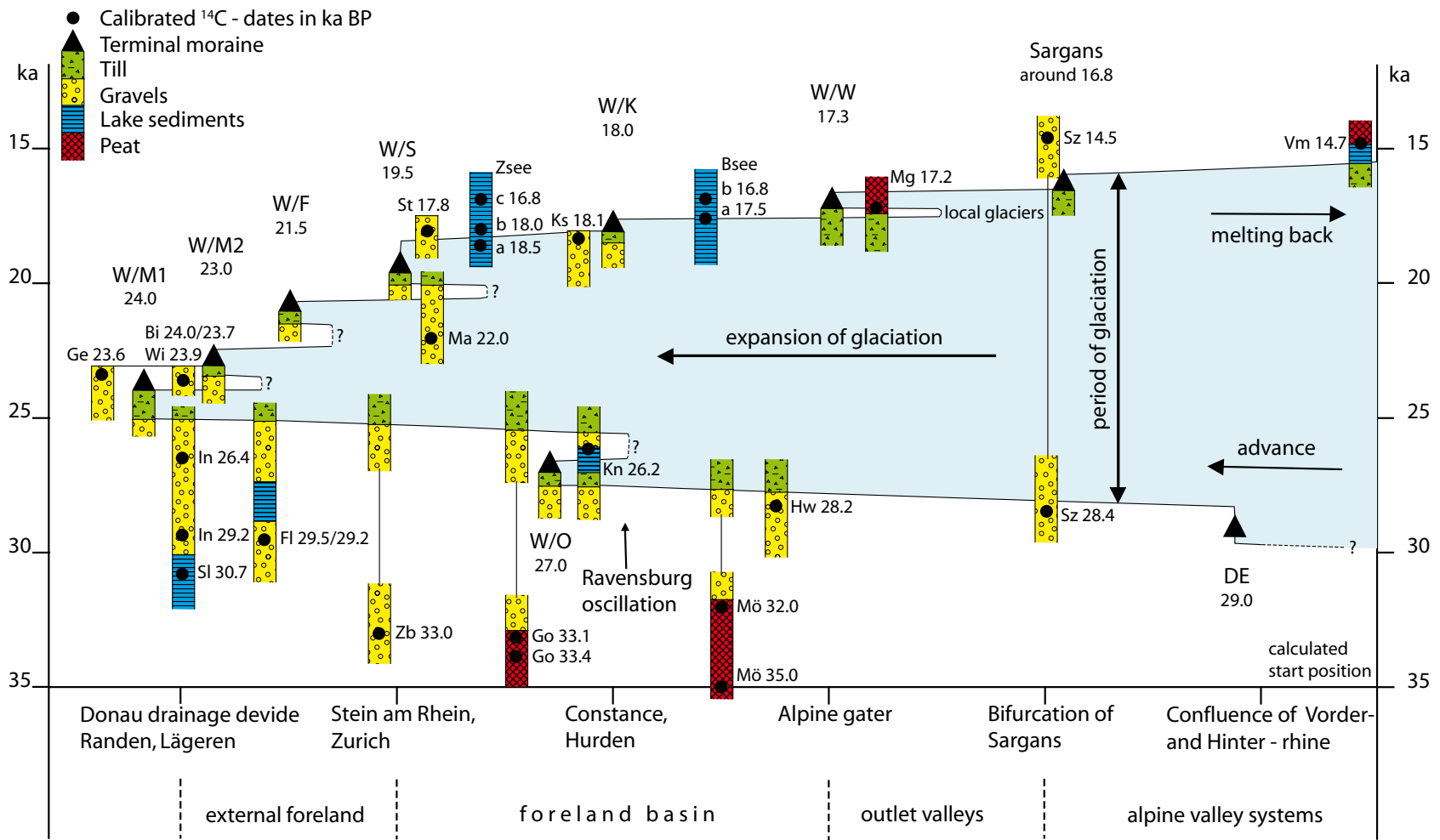

Fig. 17: Chronology of the last glacial advance of the Rhine-Linth glacier (Birrfeld/Würm; redrawn after KELLER \& KRAYSS 2005b). Ice marginal positions: $D E=$ Domat-Ems, $W / O=$ Obersee, $W / M 1=$ outer Maximum, $W / M 2=$ inner Maximum, $W / F=$ Feuerthalen, $W / S=$ Stein am Rhein, $W / K=$ Konstanz, $W / W=$ Weissbad.

Abb. 17: Chronologie des letztglazialen Eisaufbaus des Rhein-Linth Gletschers (Birrfeld/Würm; umgezeichnet nach KELLER ひ KRAYSS 2005b). Eisrandlagen: $D E=$ Domat-Ems, $W / O=$ Obersee, $W / M 1=$ äusseres Maximum, $W / M 2=$ inneres Maximum, W/F = Feuerthalen, W/S = Stein am Rhein, W/K = Konstanz, $W / W=$ Weissbad.

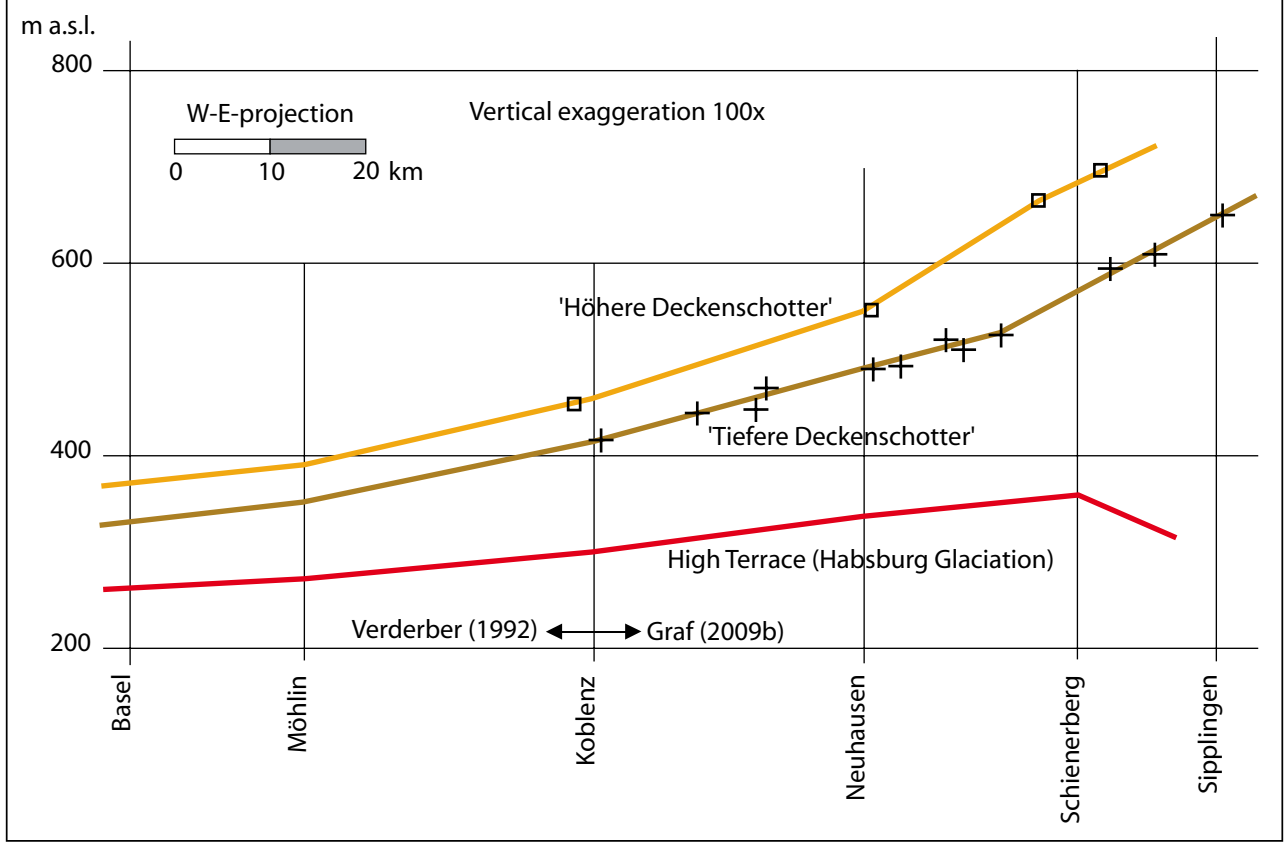

Fig. 18: Base level of gravel beds along the Hochrhein (re-drawn after KELLER \& KRAYSS 2010).

Abb. 18: Schotterbasis am Hochrhein (umgezeichnet nach KELLER \& KRAYSS 2010). 


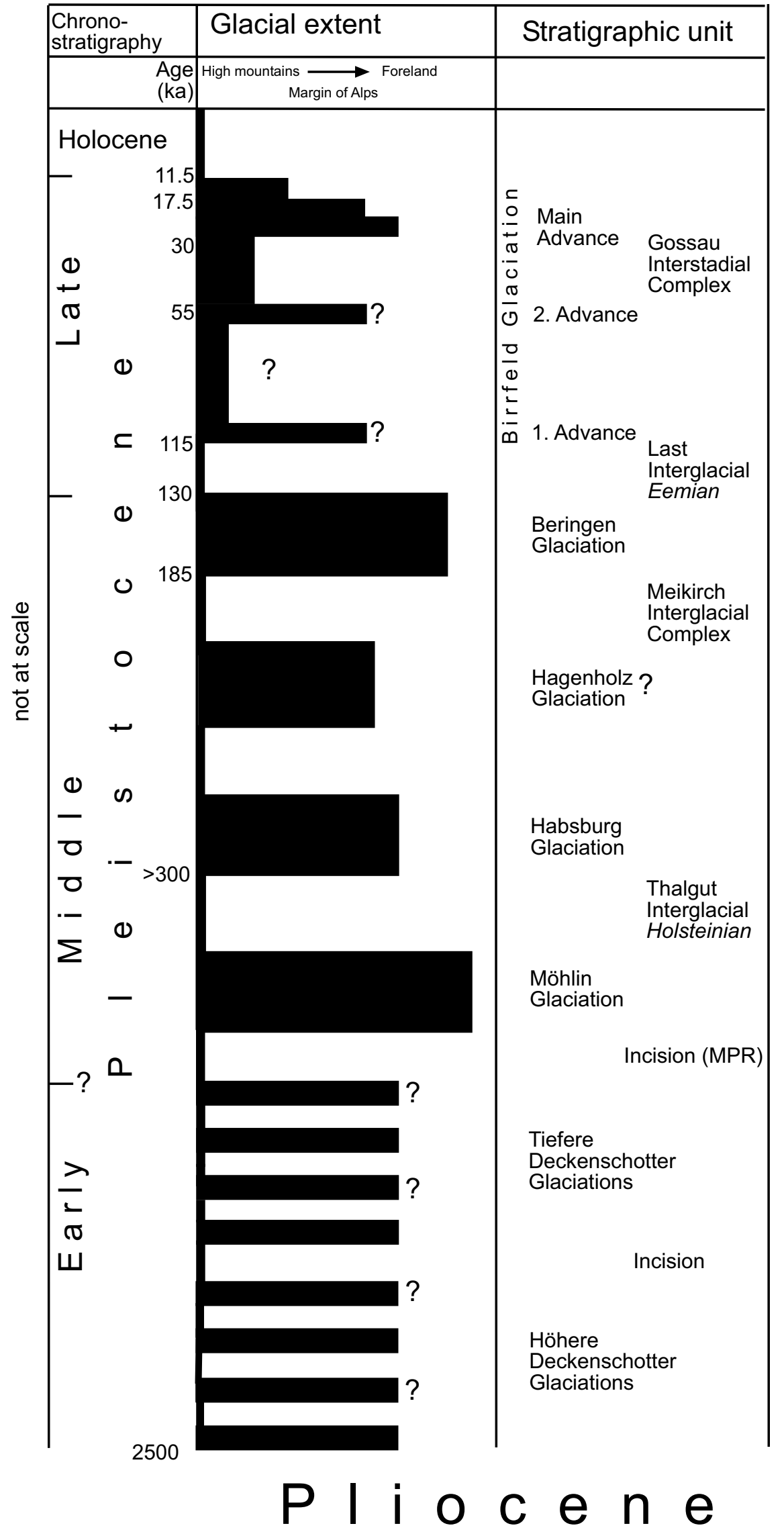

Fig. 19: Stratigraphy scheme showing the glaciation history of Switzerland. According to KELLER \& KRAYSS (2010), Hagenholz may represent an early phase of the Beringen Glaciation.

Abb. 19: Stratigraphisches Schema der Vergletscherungsgeschichte der Schweiz. Nach KELLER \& KRAYSS (2010) könnte die Hagenholz Eiszeit einer frühen Phase der Beringen Eiszeit. entsprechen. 


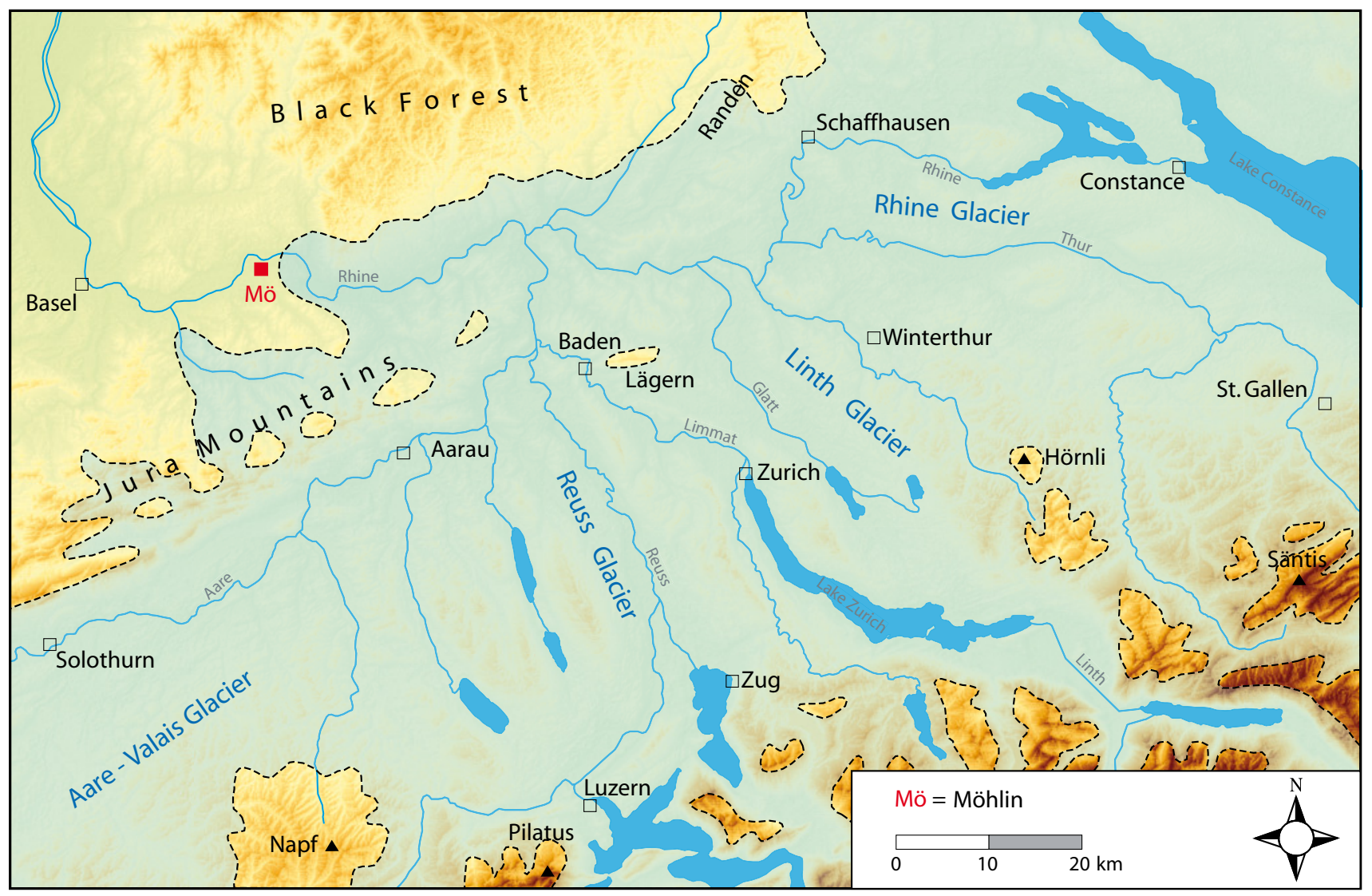

Fig. 20: Estimated maximal ice extent during the Möhlin glaciation (re-drawn after KELLER \& KRAYSS 2010; elevation data from fARVIS et al. 2008). Abb. 20: Geschätzte maximale Eisausdehnung während der Möhlin-Eiszeit (umgezeichnet nach KELLER \& KRAYSS 2010; Höhendaten von fARVIS et al. 2008).

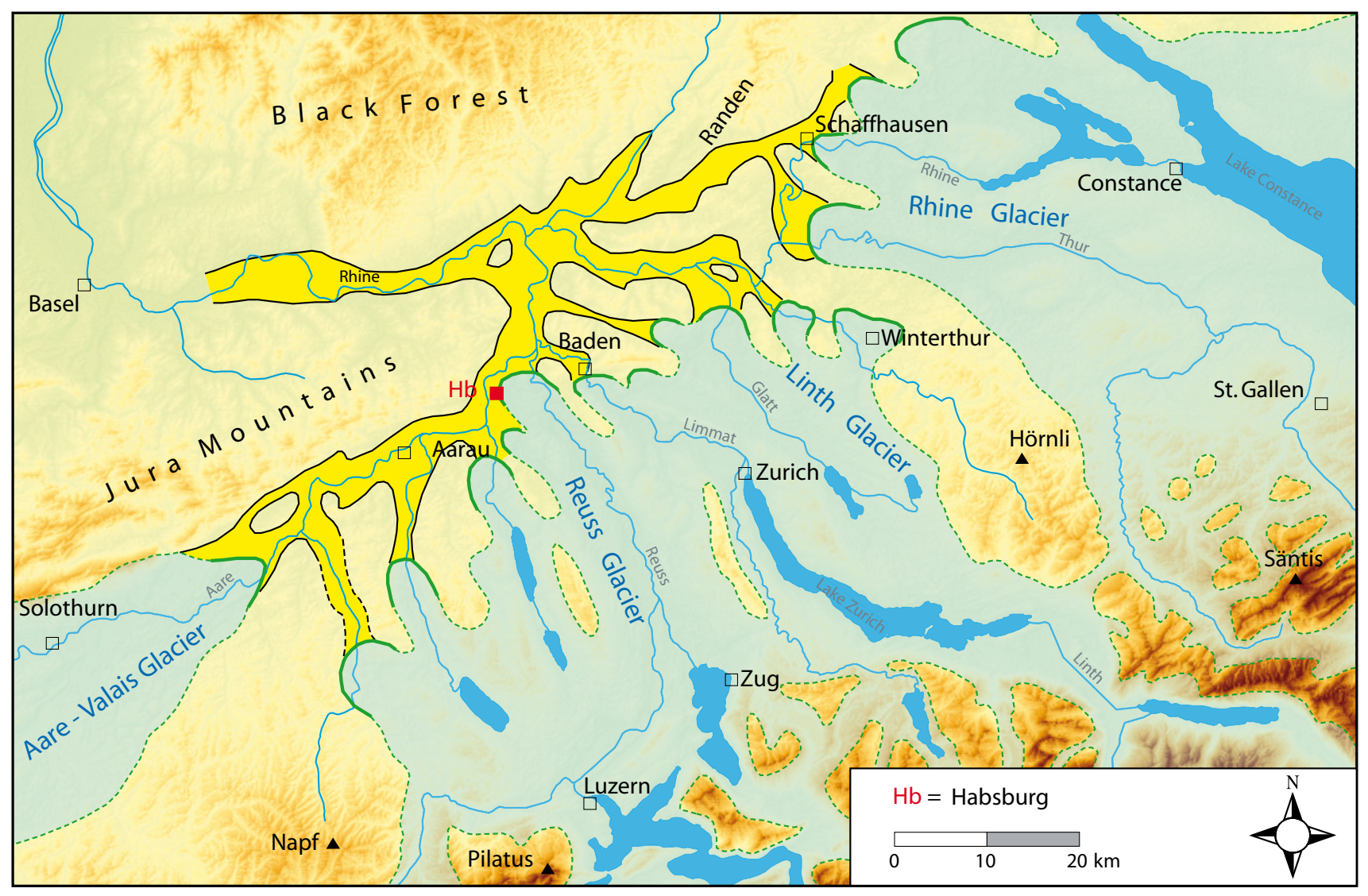

Fig. 21: Estimated maximal ice extent during the Habsburg glaciation (re-drawn after KELLER \& KRAYSS 2010; elevation data from fARVIS et al. 2008). Abb. 21: Geschätzte maximale Eisausdehnung während der Habsburg-Eiszeit (umgezeichnet nach KELLER \& KRAYSS 2010; Höhendaten von fARVIS et al. 2008). 


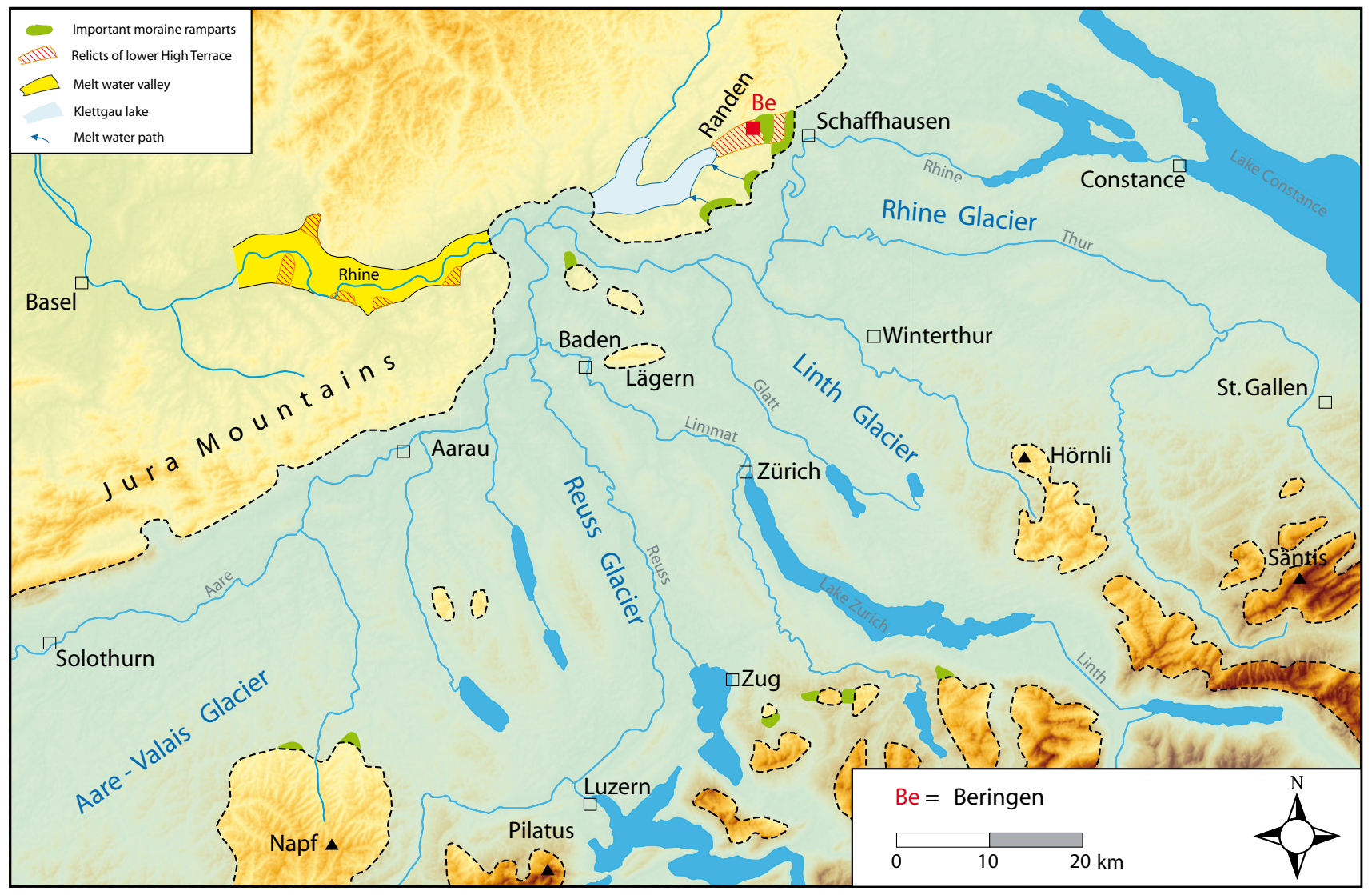

Fig. 22: Estimated maximal ice extent during the Beringen glaciation (re-drawn after KELLER \& KRAYSS 2010; elevation data from JARVIS et al. 2008). Abb. 22: Geschätzte maximale Eisausdehnung während der Beringen-Eiszeit (umgezeichnet nach KELLER \& KRAYSS 2010; Höhendaten von fARVIS et al. 2008).

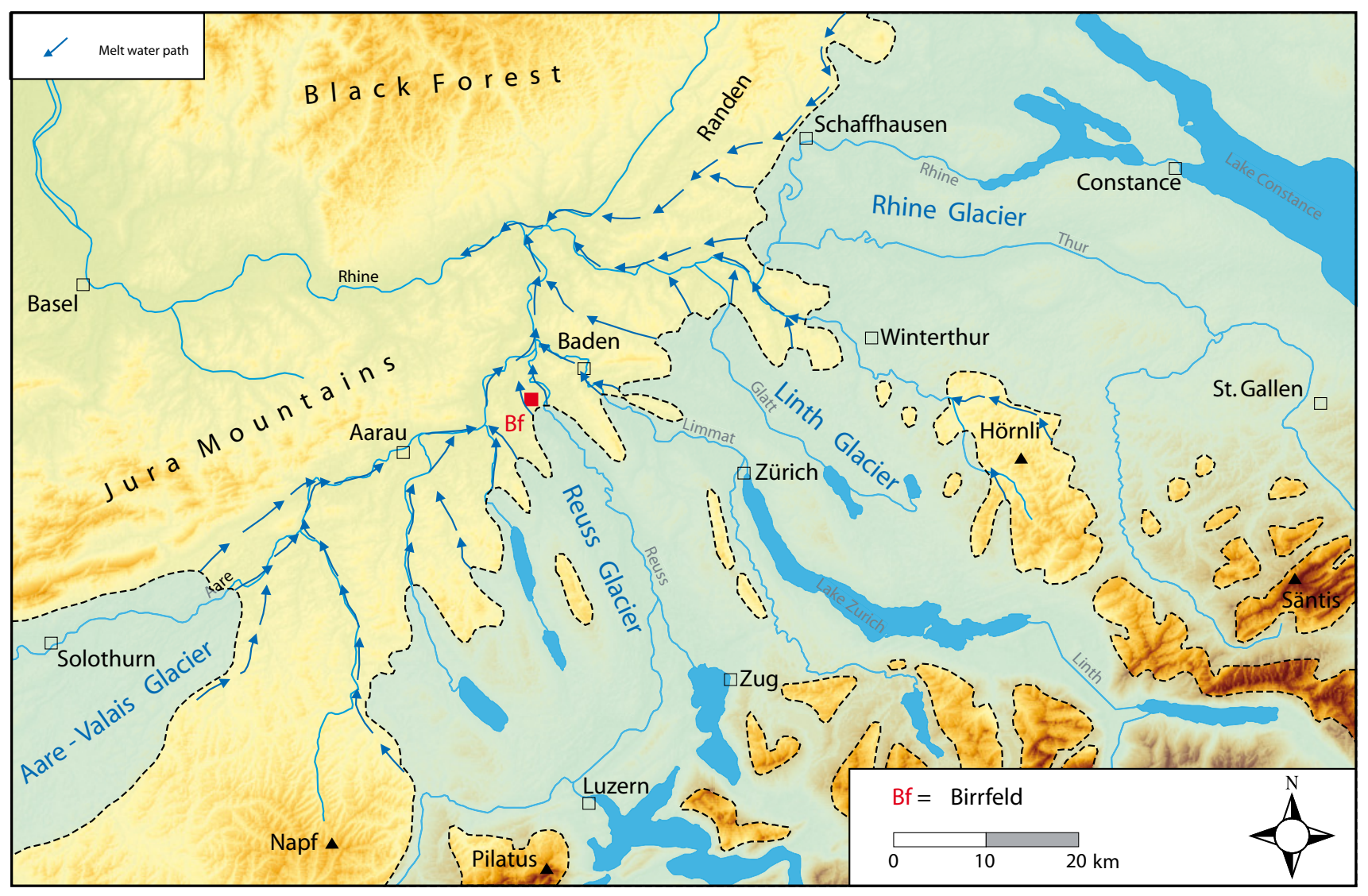

Fig. 23: Observed maximal ice extent during the Birrfeld glaciation (re-drawn after KELLER \& KRAYSS 2010; elevation data from JARVIS et al. 2008). Abb. 23: Beobachtete maximale Eisausdehnung während der Birrfeld-Eiszeit (umgezeichnet nach KELLER \& KRAYSS 2010; Höhendaten von fARVIS et al. 2008). 


\section{Glaciation history}

\subsection{Early Pleistocene ['Deckenschotter glaciations']}

During the Pliocene/Pleistocene transition, the landscape of the northern foreland of the Swiss Alps most likely had a much less pronounced relief than today. This is deduced from the fact that the channels, in which 'Höhere Deckenschotter' were deposited, have a broad and flat crosssection. Proof for glaciations reaching the Swiss lowlands during the Early Quaternary is limited and relies mainly on the presence of thin till layers within the coarse gravel deposits. It is assumed that glaciers at that time were more of a piedmont type than being valley glaciers. However, there is local evidence for glacial basins, for example, at Uetliberg near Zurich (GRAF \& MÜLLER 1999). For 'Höhere Deckenschotter', two ice advances into the lowlands are documented by the presence of glacial deposits, one reaching north of the Lägern, the other even reaching the lower Aare Valley (i.e. the region between the confluence of Aare/Reuss/Limmat and the confluence of Aare/Rhine).

Evidence for the presence of glaciers in the lowlands for the time of 'Tiefere Deckenschotter' is limited to Iberig and Schiener Berg (near Lake Constance). The till-complexes found there are much thicker than those found within 'Höhere Deckenschotter', and two ice advances are well documented by the presence of glacial sediments, at least reaching Iberig in the lower Aare Valley. Interestingly, at that time the ice advance in the Reuss Valley was apparently more pronounced than in the Rhine Valley, compared to the Last Glaciation.

An important observation is that both 'Deckenschotter' units comprise several subunits with both glacial and interglacial character, and thus probably represent at least some $100 \mathrm{ka}$. The lower bedrock level of 'Tiefere Deckenschotter' implies a period of substantial incision between both units (Fig. 18). The mechanism behind these periods of pronounced erosion could be either uplift of the Alps, or in the Jura and Black Forest, or subsidence in the Upper Rhine Graben. Both scenarios would have led to a higher gradient of the drainage system with regard to the base level in the southern part of the Upper Rhine Graben, causing incision in the upper reaches to the river systems.

Most pronounced is the incision after deposition of 'Tiefere Deckenschotter' (Fig. 18). Besides tectonic processes, this may have been caused by the redirection of the Alpine Rhine that was tributary to the River Danube during most of the Early Pleistocene (cf. Preusser 2008; Keller 2009). The connection of the Alpine Rhine, flowing at a level of about $700 \mathrm{~m}$ a.s.l., to the base level in the southern part of the Upper Rhine Graben, being at ca. $250 \mathrm{~m}$ a.s.l., must have caused substantial fluvial incision along the Hochrhein and its tributaries (systems of the Rivers Aare, Reuss, and Limmat). This complex change of drainage and relief is currently not directly dated, but we refer to it as Middle Pleistocene Reorganisation (MPR).

\subsection{Middle-Late Pleistocene of central northern Switzerland}

After the period of pronounced fluvial incision following the 'Deckenschotter' period (MPR), alpine glaciers ad- vanced to their most extensive position during the Quaternary (Fig. 19). The Möhlin Glaciation reached the southern slopes of the Black Forest (Fig. 20). Sediment attributed to this glacial advance is rare, but this glaciation probably carved the first overdeepened glacial basins in the Swiss lowlands and widened the pre-existing valleys. The following glaciation, Habsburg (Fig. 21), was of a much more limited extent compared to Möhlin and only reached to the northern margins of the deep basins in the northern Swiss lowlands, with one front of the Reuss Glacier situated near the type location of Habsburg (Fig. 21). From the terminal position of this glacial advance substantial masses of sediment where deposited along the drainage paths, i.e. the Rivers Aare and Rhine, and form part of the High Terrace deposits in these valleys. In the internal parts of the glacial basins, a continuation of glacial erosion is documented by glacial deposits (till), followed by lacustrine sedimentation. The transition to the next interglacial is often characterised by delta deposits and, in particular, peat.

Till deposits in the upper and middle parts of Glatt Valley and in the Thur Valley show intercalating lake sediments and gravel ('Aathal-Schotter') (KeMPF 1986; WyssLING 2008; MüLLER 1996), which point towards a glacial advance that probably reached the Linth and Lake Constance basins after the Habsburg Glaciation but prior to the main advance of the Beringen Glaciation. While GrAF (2009a) refers to this advance as an independent glaciation (Hagenholz), KeLLER o KRAYSS (2010) interpret it as an early advance of the Beringen Glaciation (Fig. 19).

The main advance of the Beringen Glaciation is documented by till found all over the study area in northern Switzerland. This advance has overrun the previously deposited High Terraces and crossed the River Rhine between the cities of Schaffhausen and Waldshut (Fig. 22). At the same time, the Lake Constance-Rhine Glacier advanced into the upper parts of Klettgau leaving large amounts of pro-glacial melt water deposits. Concurrently, the AareReuss-Linth Glacier blocked the lower part of Klettgau, leaving an ice-dammed lake. Outwash deposits blocked the Neuhauserwald and Engi channels, forcing the River Rhine to a southerly direction (Fig. 9). The main advance of the Beringen Glaciation left gravel on top of older lake deposits and this glacial advance likely caused the formation of some new glacial basins.

The Birrfeld Glaciation (Late Pleistocene) left a variety of geomorphological features, which are well preserved due to its relatively young age. Evidence for one or even two glacial advances during the early part of this glaciation has been discussed on several occasions (SCHLÜCHTER et al. 1987; Keller \& Krayss 1998; Preusser et al. 2003; Preusser 2004; Ivy-Ochs et al. 2008). According to present dating evidence, these glacial advances occurred during MIS 5d and/or MIS 4, and represent independent phases of ice build-up and decay (cf. Ivy-Ochs et al. 2008). Following KELlER \& KraYss (1998), the MIS 4 advance reached Untersee and was only some $10 \mathrm{~km}$ less extensive than the Last Glaciation of the Swiss lowlands.

The period between 55-30 ka was characterised by relative moderate climatic conditions, best documented by the Gossau Interstadial Complex (SCHLÜCHTER et al. 1987; Preusser et al. 2003) and to some extend at Niederweningen (FURRER et al. 2007, and references therein). The main 


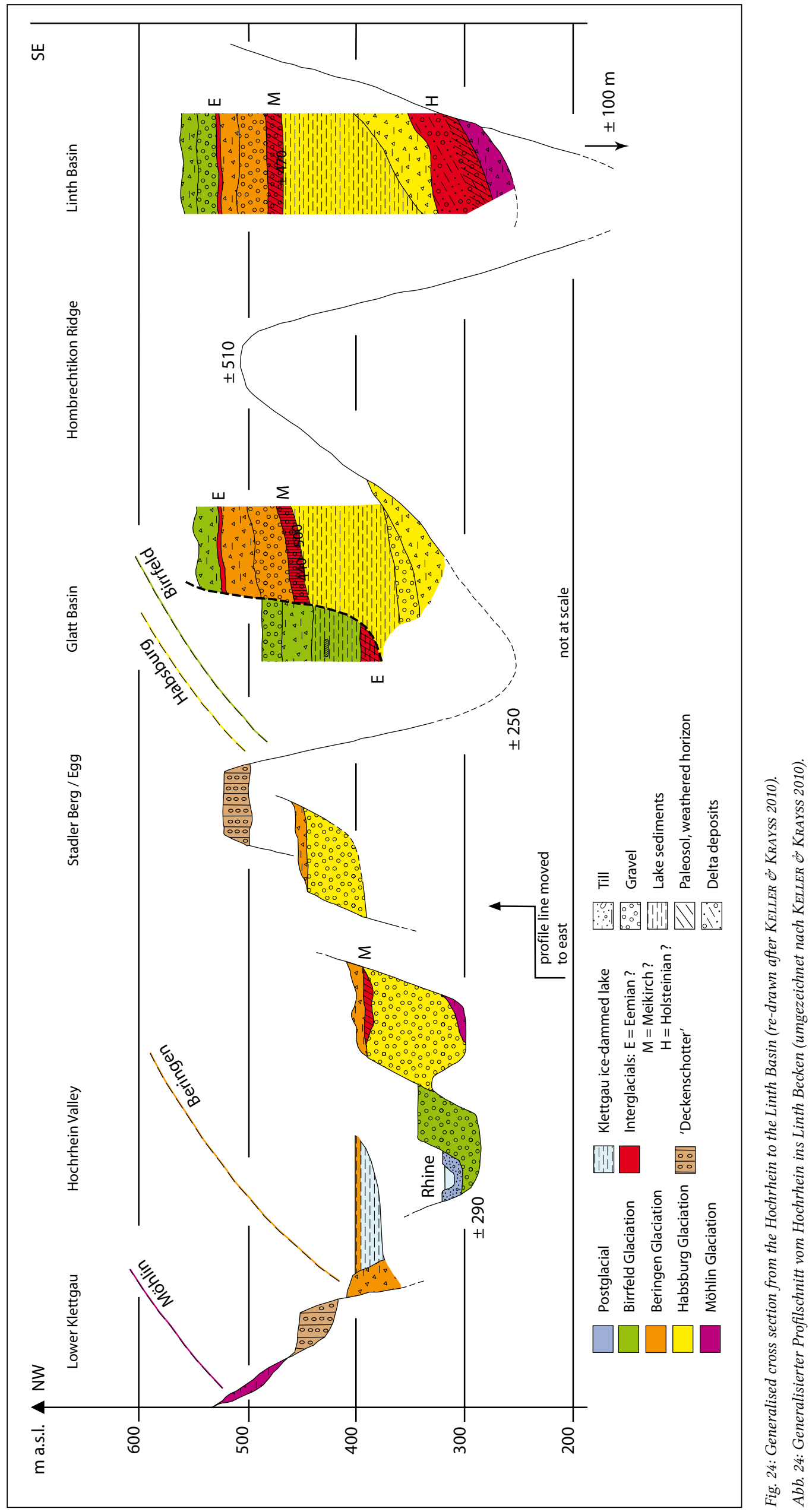




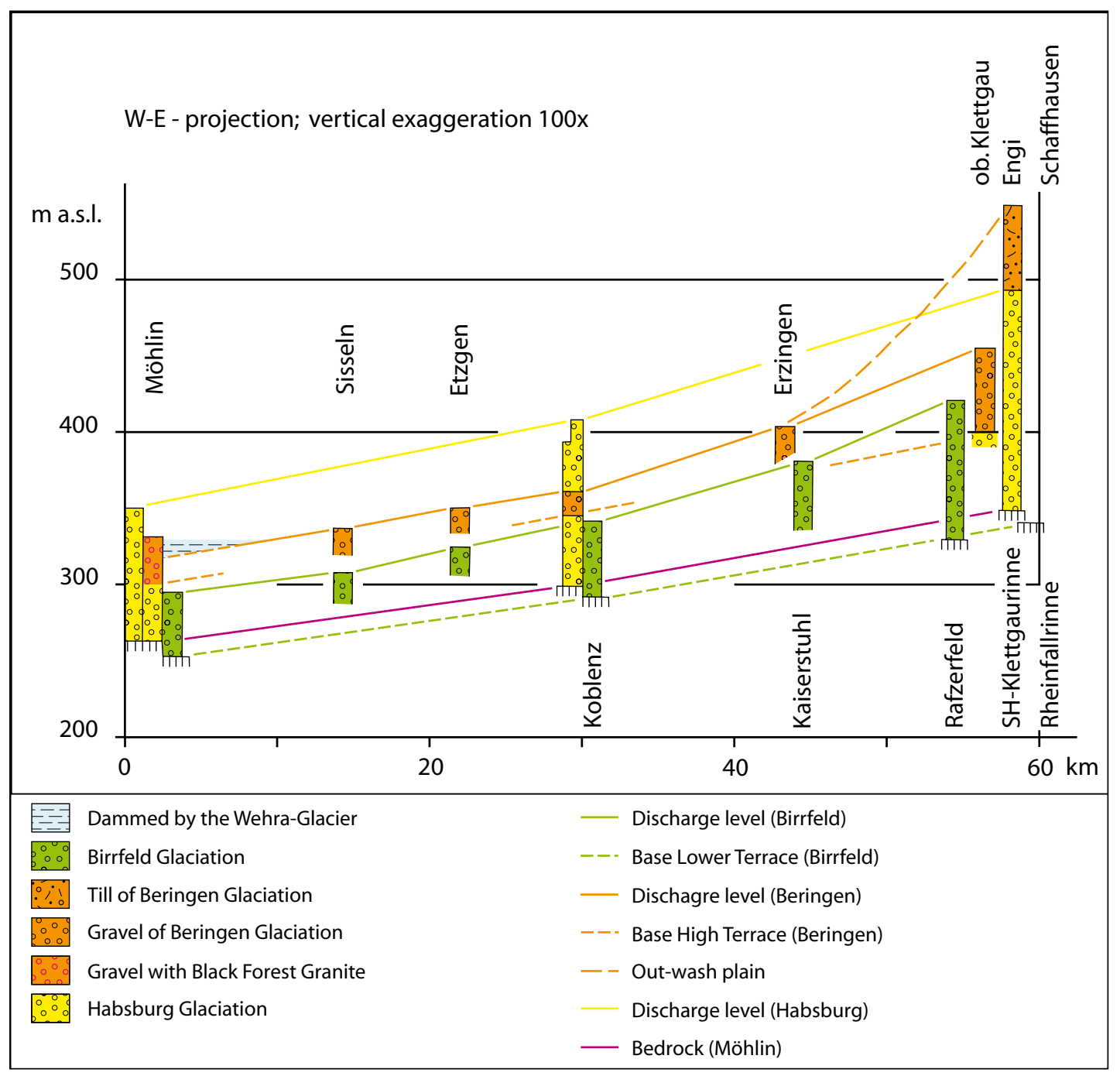

Fig. 25: Evolution of relief along the Hochrhein (re-drawn after KELLER \& KRAYSS 2010).

Abb. 25: Reliefentwicklung entlang des Hochrheins (umgezeichnet nach KELLER \& KRAYSS 2010).

advance of the Birrfeld Glaciation (Fig. 23) occurred after ca. $30 \mathrm{ka}$ ago and reached its maximum position probably about 24-22 ka. By ca. $17.5 \mathrm{ka}$ at the latest, the ice had disappeared from the Swiss lowlands (cf. Amman et al. 1994; Preusser 2004; Keller \& Krayss 2005b).

The generalised cross-section from the Linth Basin via the Glatt Valley towards the Hochrhein Valley (Fig. 24) demonstrates the impact of Quaternary glaciations on the geomorphology and summarises its imprint in the sedimentological record. In the deep basins, sedimentary successions reflect the changing depositional environments during past glacial and interglacial times. The latter are mainly represented by palaeosols and peat deposits. Incised valleys and terraces mainly made up by gravel deposits reflect ice-marginal and proglacial settings.

The evolution of the relief during the last major glaciations is shown with a west-east projection along the Hochrhein Valley between Möhlin and Schaffhausen (Fig. 25). The deep channel incised into bedrock indicates the end of erosional processes that dominated since the end of the 'Deckenschotter' period and continued until the Möhlin Glaciation. Above the base of this channel, gravel of the Habsburg Glaciation accumulated with a thickness of 70-140 m, up to the surface of the High Terrace. The elevation of the base of gravel deposition during the Beringen Glaciation is poorly known. Better constrained is the flow line of the maximum advance during this glaciation, from the proximal proglacial setting near Schaffhausen to Möhlin. During the following interglacial erosion down to the bedrock surface in partly newly incised channels was even deeper, forming the base of Low Terrace gravel with a maximal flow line originating from Rafzerfeld.

\subsection{Middle-Late Pleistocene of the Aare Valley}

Due to its geographical position, evidence from the middle part of the Aare Valley cannot directly be linked to the findings of central northern Switzerland summarised in the previous paragraphs. Nevertheless, this region is of eminent importance as most of the geochronological and palynostratigraphical information has been collected from outcrops and drill holes in this area. The oldest deposits of the region are the basal glacial sediments at Thalgut, situated below lake deposits bearing a flora with Fagus and Pterocarya. This interglacial with Pterocarya is interpreted to represent an equivalent of the Praclaux Interglacial in the Massif Central, 
France, and of the Holsteinian as defined in northern Germany (cf. BEAUlieu et al. 2001). The age of the Holsteinian is generally accepted as MIS 11 (ca. $420 \mathrm{ka}$ ) and this age is apparently verified by ${ }^{40} \mathrm{Ar} /{ }^{39} \mathrm{Ar}$ dating of tephra some metres above the Praclaux Interglacial deposits (Roger et al. 1999). In contrast, GEYH \& MÜLLER (2005) report U/Th ages of about $325 \mathrm{ka}$ for peat layers with a Holsteinian pollen signature from northern Germany, rather implying a correlation with MIS 9. Above the interglacial containing Pterocarya follows another glaciation that at least reached the Thalgut site. The Meikirch site implies the presence of a glacier at this site during MIS 8 and a complex pattern of environmental change during MIS 7, with three pronounced warm periods. The dating results from Landiswil and erratic boulders from the Jura Mountains imply an extensive glaciation of the Swiss lowland during MIS 6. First evidence from Thalgut (Preusser \& SCHLÜChtER 2004) and Finsterhennen (Preusser et al. 2007) points towards one or even two ice advances after the Last Interglacial but prior to the Last Glaciation. However, this needs to be verified by further data.

\subsection{Correlations between central northern Switzerland and the Aare Valley}

Of eminent importance for correlations and establishing a chronology is the occurrence of interglacial deposits in the Aare Valley that are present but not well investigated in the central and eastern parts of Switzerland. The oldest glaciation documented in the Aare Valley is older than Holsteinian, but we can only speculate that it is an equivalent of the Möhlin Glaciation. A glaciation younger than Holsteinian (minimum age $320 \mathrm{ka}$ ) but older than Meikirch is documented in the Aare Valley (Preusser et al. 2005) and could well be an equivalent of the Habsburg Glaciation. Considering the dating evidence from Landiswil, the Jura Mountains, and the Schaffhausen area, the extensive Beringen glaciation is likely to represent MIS 6 (ca. 180-130 ka). In northern Switzerland this advance reached beyond the River Rhine and was substantially more extensive than the last advance of the Birrfeld Glaciation.

The limited number of reliable geochronological and palynostratigraphical tie-points leaves some uncertainty with the chronological framework presented in Figure 19. However, the general scheme appears rather consistent with at least four, but probably up to seven glacial advances reaching the Swiss lowlands during the younger Middle and Late Pleistocene $(<500 \mathrm{ka})$.

\section{Conclusions}

Evidence from the northern foreland of the Swiss Alps indicates at least eight, but probably more lowland glaciations during the Quaternary. At least two glacial advances reached northern Switzerland during the time of the 'Höhere Deckenschotter' (older Early Pleistocene) and a minimum of two further advances occurred during the phase of 'Tiefere Deckenschotter' (younger Early Pleistocene to older Middle Pleistocene?). Both periods were followed by pronounced periods of fluvial incision, possible caused by tectonic movements and probably enhanced by fluvial dynamics during the second phase (re-direction of the Alpine Rhine,
MPR). The most extensive glaciation of the Quaternary is represented by the Möhlin Glaciation and is assumed to be older than Holsteinian. It is followed by the Habsburg Glaciation that was presumably of a similar size to the Last Glaciation of the Swiss lowland. The glacial extent during the subsequent Beringen Glaciation was again rather extensive. Luminescence and cosmogenic nuclide dating imply that this period is likely equivalent to MIS 6 (180-130 ka). The last glacial cycle, Birrfeld, may comprise two, or even three, periods of individual ice build-up and decay, separated by phases with relatively mild temperatures. The last glacier advance reached the lowland just after $30 \mathrm{ka}$ ago, reached its maximum ca. 24-22 ka, and disappeared from the lowlands not later than $17.5 \mathrm{ka}$.

\section{Acknowledgements}

The authors thank C. Salomé Michael for drawing most of the figures and Andreas Dehnert for providing figure 1. Andreas Dehnert and Dorian Gaar provided valuable comments on previous versions of this article. We are indebted to Philip Gibbard and Wim Westerhoff for their constructive reviews and to Sally Lowick for checking the English.

\section{References}

AgAssiz, L. (1837): Discours prononcé à l'ouverture des séances de la Société Helvétique des Sciences Naturelles. - Actes de la Société Helvétique des Sciences Naturelles, Neuchâtel.

Amman, B., Lotter, A., Eicher, U., Gaillard, M.-J., Wohlfarth, B., Haeberli, W., Lister, G., Maisch, M., Niessen, F. \& Schlüchter, CH. (1994): The Würmian Late-glacial in lowland Switzerland. - Journal of Quaternary Science, 9: 119-125.

Beaulieu, J.-L. de, Andrieu-Ponel, V., Reille, M., Grüger, E., Tzedakis, C. \& Svobodova, H. (2001): An attempt at correlation between the Velay pollen sequence and the Middle Pleistocene stratigraphy from central Europe. - Quaternary Science Reviews, 20: 1593-1602.

Bini, A., Buoncristiani, J.-F., Couterrand, S., Ellwanger, D., Felber, M., Florineth, D., Graf, H.R., Keller, O., Kelly, M., Schlüchter, C., \& Schoeneich, P. (2009): Die Schweiz während des letzteiszeitlichen Maximums (LGM). - Map $1: 500$ 000, swisstopo.

Bolliger, T., Feijfar, O., Graf, H.R. \& Kälin, D.W. (1996): Vorläufige Mitteilung über Funde von pliozänen Kleinsäugern ais den Höheren Deckenschottern des Irchels (Kt. Zürich). - Eclogae geologicae Helvetiae, 89: 1043-1048.

Brockmann-Jerosch, H. (1910): Die fossilen Pflanzenreste des glazialen Deltas bei Kaltbrunn (bei Uznach, Kanton St. Gallen) und deren Bedeutung für die Auffassung des Wesens der Eiszeit. - Jahrbuch St. Gallische Naturwissenschaftliche Gesellschaft. Habilschrift Universität Zürich.

Charpentier, J. DE (1841): Essai sur les glaciers et sur le terrain erratique di Bassin du Rhône.

Dehnert, A., Preusser, F., Kramers, J.D., Akçar, N., Kubik, P.W., Reber, R. \& SCHLÜCHTER, C. (2010): A multi-dating approach applied to proglacial sediments attributed to the Most Extensive Glaciation of the Swiss Alps. - Boreas, 39: 620-632.

EberL, B. (1930): Die Eiszeitenfolge im nördlichen Alpenvorland. - Benno Filser Verlag, Augsburg.

Fiebig, M. $\mho$ Preusser, F. (2003): Das Alter fluvialer Ablagerungen aus der Region Ingolstadt (Bayern) und ihre Bedeutung für die Eiszeitenchronologie des Alpenvorlandes. - Zeitschrift für Geomorphologie Neue Folge, 47: 449-467.

Florineth, D. (1998): Surface geometry of the Last Glacial Maximum (LGM) in the southeastern Swiss Alps (Graubünden) and its paleoclimatological significance. - Eiszeitalter und Gegenwart, 48: 23-37.

Florineth, D. \& SCHLÜCHTER, C. (1998): Reconstructing the Last Glacial Maximum (LGM) ice surface geometry and lowlines in the Central Swiss Alps. - Eclogae geologicae Helvetiae, 91: 391-407.

Florineth, D. \& SChlÜChter, C. (2000): Alpine evidence for atmospheric circulation patterns in Europe during the Last Glacial Maximum. Quaternary Research, 54: 295-308. 
Furrer, H., Graf, H.R. $\mho$ MäDER, A. (2007): The mammoth site of Niederweningen, Switzerland. - Quaternary International, 164-165: 85-97.

Gerber, E. (1941): Über Höhenschotter zwischen Emmental und Aaretal. - Eclogae geologicae Helvetiae, 34: 1-16.

Gerber, E. (1950): Blatt 22: Fraubrunnen - Wynigen - Hindelbank - Burgdorf (SA 142-145), mit nördlichem Teil von Blatt 321 Bigenthal. Erläuterungen zum Geologischer Atlas der Schweiz 1: 25 000. - Bundesamt für Landestopographie, Bern.

GEYH, M.A. \& MÜLLER, H. (2005): Numerical 230Th/U dating and a palynological review of the Holsteinian/Hoxonian Interglacial. - Quaternary Science Reviews, 24: 1861-1872.

Graf, A.A., Strasky, S., Ivy-Ochs, S., Akçar, N., Kubik, P. W., Burkhard, M. \& SCHLÜCHTER, C. (2007): First results of cosmogenic dated pre-Last Glaciation erratics from the Montoz area, Jura Mountains, Switzerland. - Quaternary International, 164-165: 43-52.

Graf, H.R. (1993): Die Deckenschotter der Zentralen Nordschweiz. - Diss ETH Zürich Nr. 10205, 151 S.

Graf, H.R. (2009a): Stratigraphie von Mittel- und Spätpleistozän in der Nordschweiz. - Beiträge zur Geologischen Karte der Schweiz, 168, Bundesamt für Landestopografie swisstopo, Wabern.

GRAF, H.R. (2009b): Stratigrafie und Morphogenese von frühpleistozänen Ablagerungen zwischen Bodensee und Klettgau. E\&G - Quaternary Science Journal 58, 12-54.

Graf, H.R. \& MÜLler, B. (1999): Das Quartär: Die Epoche der Eiszeiten In: Bolliger, Th. (Ed.) Geologie des Kantons Zürich, 71-95, Ott Verlag, Thun.

GRuner, U. (2001): Blatt 104: Worb (LK 1167). Erläuterungen zum Geologischer Atlas der Schweiz $1: 25$ 000. - Bundesamt für Landestopographie, Bern.

Ivy-Ochs, S., Schäfer, J., Kubik, P.W., Synal, H.-A. \& Schlüchter, C. (2004): Timing of deglaciation on the northern alpine foreland (Switzerland). - Eclogae geologicae Helvetiae, 97: 47-55.

Ivy-Ochs, S., Kerschner, H., Reuther, A., Preusser, F., Heine, K., Kubik, P.W., Maisch, M. \& Schlüchter, C. (2008): Chronology of the last glacial cycle in the European Alps. - Journal of Quaternary Science, 23: 559-573.

Ivy-Ochs, S., Kerschner, H., Maisch, M., Chritl, M., Kubik, P.W. \& SCHLÜCHTER, C. (2009): Latest Pleistocene and Holocene glacier variations in the European Alps. Quaternary Science Reviews, 28 2137-2149.

Haldimann, P.A. (1978): Quartärgeologische Entwicklung des mittleren Glattals (Kt. Zürich). - Eclogae geologicae Helvetiae, 71: 347-355.

Jarvis A., Reuter, H.I., Nelson, A., Guevara, E. (2008): Hole-filled seamless SRTM data V4, International Centre for Tropical Agriculture (CIAT). (available from http://srtm.csi.cgiar.org)

JeAnNet, A. (1923): Les charbons feuilletés de la vallée de la Linth entre le lacs de Zurich et de Walenstadt. In: BAumberger, E., Gerber, E., JeANNET, A. \& WebER J. (Eds.): Die diluvialen Schieferkohlen der Schweiz. Beiträge Geologie der Schweiz, geotechnische Serie VIII, 106-370.

Keller, O. (1994): Entstehung und Entwicklung des Bodensees - ein geologischer Lebenslauf. - In: MAURER, H. (Ed.): Umweltwandel am Bodensee. - Fachverlag UVK, 33-92; St. Gallen, Konstanz.

Keller, O. (2005): Letzte Eiszeit und Landschaftsformung am Hochrhein und am Alpenrhein. - In: Der Rhein - Lebensader einer Region. Neujahrsblatt der Naturforschenden Gesellschaft in Zürich, 54-74.

Keller, O. (2009): Als der Alpenrhein sich von der Donau zum Oberrhein wandte. - Schriften des Vereins für Geschichte des Bodensees und seiner Umgebung, 127: 193-208.

Keller, O. \& Krayss, E. (1998): Datenlage und Modell einer Rhein-LinthVorlandvergletscherung zwischen Eem-Interglazial und Hochwürm. GeoArchaeoRhein, 2: 121-138.

Keller, O. ¿ KraYss, E. (1999): Quartär und Landschaftsgeschichte. - Erläuterungen zur Geologischen Übersichtskarte des Kantons Thurgau. - Mitteilungen der Thurgauischen Naturforschenden Gesellschaft, 55: 39-67.

Keller, O. ¿ Krayss, E. (2005a): Der Rhein-Linth-Gletscher im letzten Hochglazial. 1. Teil: Einleitung; Aufbau und Abschmelzen des RheinLinth-Gletschers im Oberen Würm. - Vierteljahrsschrift der Naturforschenden Gesellschaft in Zürich, 150: 19-32.

Keller, O. \& Krayss, E. (2005b): Der Rhein-Linth-Gletscher im letzten Hochglazial. 2. Teil: Datierung und Modelle der Rhein-Linth-Vergletscherung. Klima-Rekonstruktionen. - Vierteljahrsschrift der Naturforschenden Gesellschaft in Zürich, 150: 69-85.

Keller, O. \& Krayss, E. (2010): Mittel- und spätpleistozäne Stratigraphie und Morphogenese in Schlüsselregionen der Nordschweiz. - E\&G Quaternary Science Journal, 59: 88-119.
Kelly, M.A., Buoncristiani, J.-F. \& SchlÜchter, C. (2004): A reconstruction of the last glacial maximum (LGM) ice-surface geometry in the western Swiss Alps and contiguous Alpine regions in Italy and France. - Eclogae geologicae Helvetiae, 97: 57-75.

KempF, T. (1986): In: Direktion der öffentlichen Bauten des Kantons Zürich Die Grundwasservorkommen im Kanton Zürich, Erläuterungen zur Grundwasserkarte des Kantons Zürich $1: 25$ 000, 211 S. - Beiträge zur Geologie der Schweiz, Geotechnische Serie 69; ETH 8092 Zürich.

Kock, S., Huggenberger, P., Preusser, F., Rentzel, P. \& Wetzel, A (2009): Formation and evolution of the Lower Terrace of the Rhine River in the area of Basel. - Swiss Journal of Geosciences, 102: 307-321.

Longo, W. (1978): Geologie des Hagenholztunnels bei Kloten. - Eclogae geologicae Helvetiae, 71: 175-182.

Mailänder, R. $\mho$ Veit, H. (2001): Periglacial cover beds on the Swiss Plateau: indicators of soil, climate and landscape evolution during the Late Quaternary. - Catena, 45: 251-272.

MÜLLER, E.R. (1996): Die Ittinger Schotter und ihr morphogenetisches Umfeld. - Eclogae geologicae Helvetiae, 89: 1077-1093.

Penck, A. \& Brückner, E. (1901/09): Die Alpen im Eiszeitalter. - Tauchnitz, Leipzig

Preusser, F. (1999): Luminescence dating of fluvial sediments and overbank deposits from Gossau, Switzerland: fine grain dating. - Quaternary Science Reviews 18: 217-222.

Preusser, F. (2004): Towards a chronology of the Upper Pleistocene in the northern Alpine Foreland. - Boreas, 33: 195-210.

Preusser, F. (2008): Characterisation and evolution of the River Rhine system. - Netherlands Journal of Geosciences, 87: 7-19.

Preusser, F., Geyh., M.A. \& Schlüchter, C. (2003): Timing of Late Pleistocene climate change in lowland Switzerland. - Quaternary Science Reviews, 22: 1435-1445.

Preusser, F. \& Graf, H.R. (2002): Erste Ergebnisse von Lumineszenzdatierungen eiszeitlicher Ablagerungen der Nordschweiz. - Jahrbuch und Mitteilungen des Oberrheinischen Geologischen Vereins, 107: 419-438.

Preusser, F. \& Schlüchter, C. (2004): Dates from an important early Late Pleistocene ice advance in the Aare Valley, Switzerland. - Eclogae geologicae Helvetiae, 97: 245-253.

Preusser, F., Drescher-Schneider, R., Fiebig, M. \& Schlüchter, C. (2005): Re-interpretation of the Meikirch pollen record, Swiss Alpine Foreland, and implications for Middle Pleistocene chronostratigraphy. - Journal of Quaternary Science, 20: 607-620.

Preusser, F., Blei, A., Graf, H.R. \& Schlüchter, C. (2007): Luminescence dating of proglacial sediments from Switzerland. - Boreas, 36: 130-142.

Preusser, F., Reitner, J. \& Schlüchter, C. (2010). Distribution, geometry, age and origin of overdeepened valleys and basins in the Alps and their foreland. Swiss Journal of Geosciences, 103: 407-427.

Roger, S., Féraud, G., de Beaulieu, J.-L., Thouveny, N., Coulon, Ch., Choucemé, J.J., Andrieu, V. \& Williams, T. (1999): ${ }^{40} \mathrm{Ar} /{ }^{39} \mathrm{Ar}$ dating on tephra of the Velay maars (France): implications for the Late Pleistocene proxy-climatic record. - Earth and Planetary Science Letters, 170: $287-299$.

Schatfer, I. (1957) : Erläuterungen zur Geologischen Karte von Augsburg und Umgebung 1:50 000. - Bayrisches Geologisches Landesamt München.

SCHINDLER, C. (2004): Zum Quartär des Linthgebietes zwischen Luchsingen, dem Walensee und dem Zürcher Obersee. - Beiträge zur Geologischen Karte der Schweiz, 159 S. - Bundesamt für Landestopografie swisstopo; Wabern.

SCHLÜCHTER, C. (1987a): Lokale Vergletscherung im westlichen Ausläufer des Napfberglandes. - Eiszeitalter und Gegenwart, 37: 41-45.

SchlÜCHTER, C. (1987b): Talgenese im Quartär - eine Standortbestimmung. Geographica Helvetica, 2: 109-115.

SCHLÜCHTER, C. (1988): A non-classical summary of the Quaternary stratigraphy in the northern alpine Foreland of Switzerland. - Bulletin de la Société neuchâteloise de géographie, 32: 143-157.

SCHLÜCHTER, C. (1989a): The most complete Quaternary record of the Swiss Alpine Foreland. - Palaeogeography, Palaeoclimatology, Palaeoecology, 72: 141-146.

SCHLÜCHTER, C. (1989b): Thalgut: Ein umfassendes eiszeitstratigraphisches Referenzprofil im nördlichen Alpenvorland. - Eclogae geologicae Helvetiae, 82: 277-284.

Schlüchter, C., Maisch, M., Suter, J., Fitze, P., Keller, W.A., Burga, C.A. \& Wynistorf, E. (1987): Das Schieferkohlenprofil von Gossau (Kanton Zürich) und seine stratigraphische Stellung innerhalb der letzten Eiszeit. - Vierteljahrsschrift der Naturforschenden Gesellschaft in Zürich, 132: 135-174. 
Schlüchter, C. ¿ Kelly, M. (2000): Das Eiszeitalter in der Schweiz. - Stiftung Landschaft und Kies, Uttigen.

SCHReINER, A. \& EBEL, R. (1981): Quartärgeologische Untersuchungen in der Umgebung von Interglazialvorkommen im östlichen Rheingletschergebiet (Baden-Württemberg). - Geologisches Jahrbuch, A59: 3-64.

VenETZ, I. (1833): Mémoire sur les variation de la temperature dans les Alps de la Suisse. - Denkschriften der allgemeinen Schweizerischen Gesellschaft für die gesamte Natur, 1.

VenetZ, I. (1861): Mémoire sur l'extension des ancient glaciers, renfermant quelques explications sur leurs effects remarquables. - Neue Denkschrift der allgemeinen Schweizerischen Gesellschaft für die gesamte Natur, 18.
WeLten, M. (1982): Pollenanalytische Untersuchungen im Jüngeren Quartär des nördlichen Alpenvorlandes der Schweiz. - Beiträge zur Geologischen Karte der Schweiz N. F. 156, 174 pp.; Bern.

Welten, M. (1988): Neue pollenanalytische Ergebnisse über das Jüngere Quartär des nördlichen Alpenvorlandes der Schweiz (Mittel- und Jungpleistozän). - Beiträge zur Geologischen Karte der Schweiz N.F. 162, 40 pp.; Bern.

Wyssling, L. \& WyssLing, G. (1978): Interglaziale Seeablagerungen in einer Bohrung bei Uster (Kt. Zürich). - Eclogae geologicae Helvetiae, 71: $357-375$.

WyssLING, G. (2008): Blatt 1092 Uster. Geologischer Atlas der Schweiz, Erläuterungen 128. - Bundesamt für Landestopografie swisstopo; Wabern. 